$$
\text { UNIVERSIDADE DE BRASÍLIA - UNB }
$$

FACULDADE DE ECONOMIA, ADMINISTRAÇÃO, CONTABILIDADE E CIÊNCIA DA INFORMAÇÃO E DOCUMENTAÇÃO - FACE

VANESSA LIMA SILVA

TOMADA DE CONTAS ESPECIAL DE CONVÊNIOS: UMA ANÁLISE CRÍTICA DA VIABILIDADE DO PORTAL DE CONVÊNIOS NA TOMADA DE CONTAS ESPECIAL REALIZADA PELO TCU 
VANESSA LIMA SILVA

\title{
TOMADA DE CONTAS ESPECIAL DE CONVÊNIOS: UMA ANÁLISE CRÍTICA DA VIABILIDADE DO PORTAL DE CONVÊNIOS NA TOMADA DE CONTAS ESPECIAL REALIZADA PELO TCU
}

\begin{abstract}
Monografia apresentada ao Programa de Pós-Graduação em Administração (PPGA) da Faculdade de Economia, Administração, Contabilidade e Ciência da Informação e Documentação (FACE), da Universidade de Brasília, como requisito parcial à obtenção do grau de Especialista em Orçamento e Finanças
\end{abstract}

Orientador: Gilvan Dantas 


\section{RESUMO}

Este trabalho insere-se no campo das finanças públicas e está focado no estudo do processo de tomada de contas referente aos convênios celebrados com a União. O estudo abrange os fatores que motivaram a criação de uma nova abordagem para a operacionalização das transferências voluntárias de recursos de União, as principais mudanças na legislação dos convênios e descreve os principais aspectos do Sistema de Gestão de Convênios - SICONV. A partir daí chegar-se ao seu objetivo principal que é o de realizar uma análise sobre a viabilidade de utilização do Portal de Convênios para auxiliar o processo de tomada de contas especial, realizado pelo Tribunal de Contas da União, referente às transferências voluntárias da União para Estados, Municípios e Entidades Privadas sem Fins Lucrativos, mediante convênios.

Palavras-chave: Tomada de Contas. Transferências Voluntárias. Convênios. 


\section{LISTA DE FIGURAS}

Figura 1 - Requisitos para celebração de convênios................................................... 24

Figura 2 - Aspectos avaliados no parecer técnico........................................................ 24

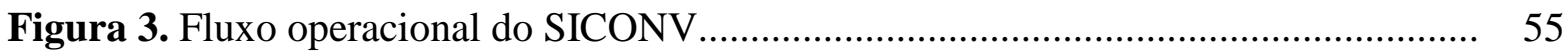

Figura 4. Módulo da celebração............................................................................... 56

Figura 5. Módulos de execução e prestação de contas...................................................... 57

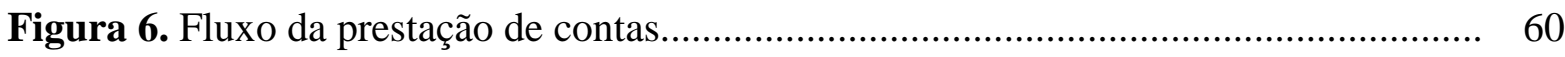

\section{LISTA DE QUADROS:}

Quadro 1. Limites de Contrapartida Municípios, Estados e Distrito Federal................... 22

Quadro 2. Comparativo sobre credenciamento....................................................... 49

Quadro 3. Comparativo sobre cadastramento......................................................... 50

Quadro 4. Comparativo sobre proposição................................................................... 51

Quadro 5. Comparativo sobre pagamento.................................................................... 52 


\section{LISTA DE TABELAS}

Tabela 1. Convênios com problemas......................................................................... 43

Tabela 2. Convênios sem prestação de contas.................................................................. 44

Tabela 3. Transferências a Estados e Municípios............................................................ 44

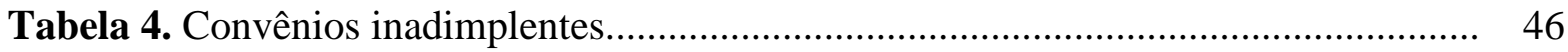

Tabela 5. Convênios com inadimplência suspensa.......................................................... 47 


\section{SUMÁRIO}

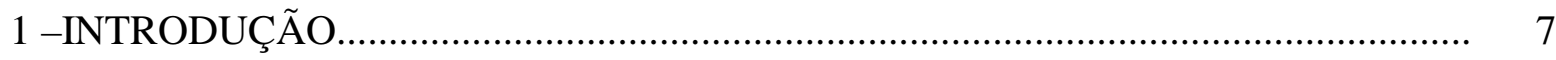

1.1 - Formulação do problema de pesquisa ................................................................ 8

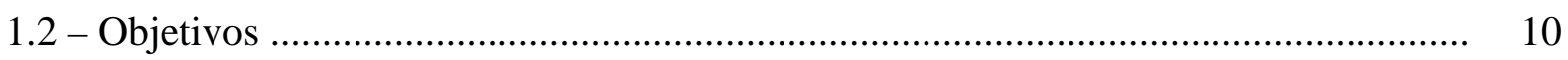

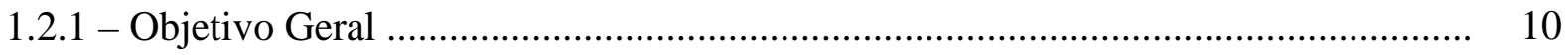

1.2.2 - Objetivos Específicos .............................................................................. 10

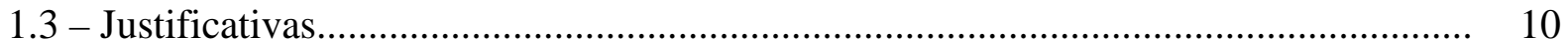

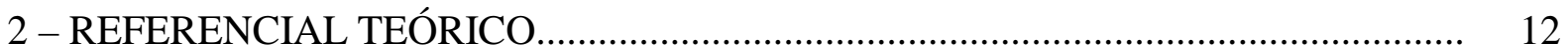

2.1 - Transferências de recursos da União................................................................ 12

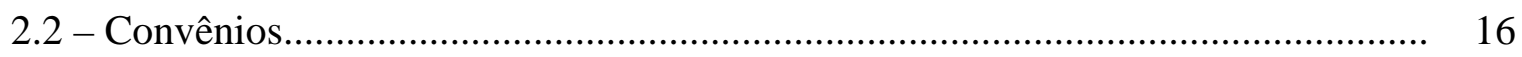

2.2.1- Histórico Legal....................................................................................... 16

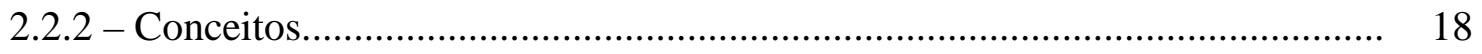

2.2.3 - Fases do convênio..................................................................................... 20

2.2.3.1 - Proposição.................................................................................. 20

2.2.3.2 - Celebração................................................................................. 23

2.2.3.3 - Execução.................................................................................... 26

2.2.3.3.1. - Fiscalização de convênios.................................................... 28

2.2.3.4 - Prestação de Contas............................................................................. 29

2.3 - O controle na Administração Pública.................................................................. 31

2.3.1 - O controle interno................................................................................... 34

2.3.2 - O controle externo..................................................................... 35

2.4 - Tomada de contas especial.......................................................................... 37

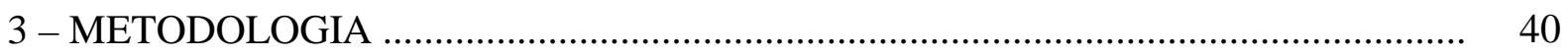

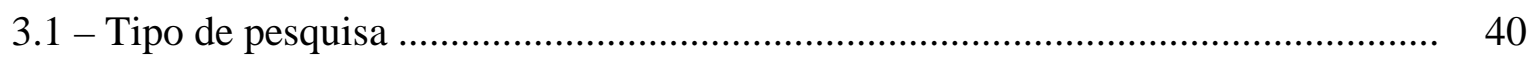

3.2 - Caracterização da organização..................................................................... 40

3.3 - Participantes da pesquisa amostra de documentos.............................................. 41

3.3.1 - Critério de Seleção de participantes ou da amostra........................................ 41

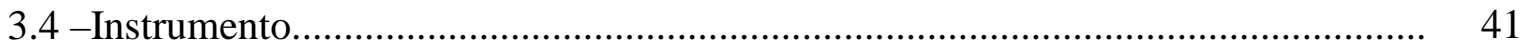

3.5 - Procedimentos de coleta dos dados ................................................................. 41

3.6 - Análise dos dados ................................................................................... 42

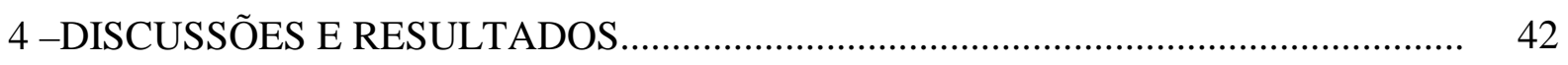

4.1 - Principais fatores que motivaram a criação do Sistema de Gestão de Convênios 42 
4.2 - Principais mudanças ocorridas na legislação dos convênios................................. 48

4.3 - O Sistema de Gestão de Convênios - SICONV .................................................... 54

4.4 - A Tomada de Contas Especial e o SICONV ...................................................... 58

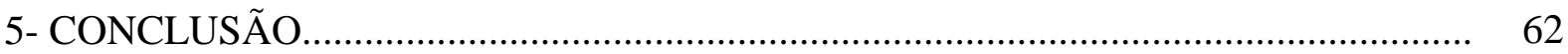

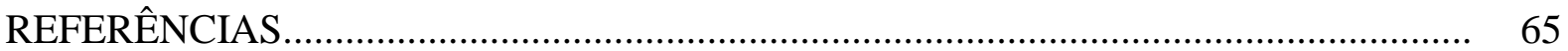




\title{
1 - Introdução
}

Este trabalho insere-se no campo das finanças públicas principalmente no tocante ao controle das transferências voluntárias de recursos da União mediante convênios.

“As descentralizações de recursos a Estados, Municípios, Distrito Federal e entidades privadas, destinadas à realização de ações cuja competência seja da União ou tenham sido delegadas aos entes Federados, com ônus para a União, são chamadas de transferências voluntárias”. (BASTOS NETO, 2008, p.17).

Os convênios, forma de operacionalização das transferências voluntárias, segundo Meireles (2003, p.386) "são como acordos firmados por entidades públicas de qualquer espécie, ou entre estas e organizações particulares, para realização de objetivos de interesse comum dos participes".

Conforme dados obtidos junto a Secretaria do Tesouro Nacional, no período de 2002 a 2008, houve um acréscimo de mais de $80 \%$ nos valores transferidos voluntariamente pela União. (BASTOS NETO, 2008).

Lambranho e Militão (2008) revelam que:

\begin{abstract}
Dados consultado no SIAFI, desde 1987, até o último dia 08 de dezembro de 2008, mostram que R\$70,3 bilhões em transferências de recursos da União para prefeituras, estados e organizações não-governamentais (ONGs) não foram alvo de nenhuma fiscalização sobre a aplicação do dinheiro público durante os últimos 21 anos. Há cerca de R\$ 937,43 milhões em convênios que deveriam ser alvo de investigação porque os órgãos públicos ou ONGs estão inadimplentes na prestação de contas.
\end{abstract}

Com base nos dados apresentados, podemos concluir que uma grande maioria dos recursos transferidos, não estão sendo alvo de nenhuma fiscalização sobre a boa aplicação do recurso. Fato preocupante, já que os recursos em questão são dinheiro público e devem ser aplicados em beneficio do interesse público, com a devida comprovação do gasto.

Sobre a prestação de contas Lambranho e Militão (2008), lembram que:

\begin{abstract}
Muitos convênios deveriam ser alvo de investigação, visto que os órgãos públicos ou ONGs estão inadimplentes na prestação de contas. Ou seja, não apresentaram adequadamente a comprovação dos gastos ou repassaram dados que foram rejeitados pela própria União. Apesar disso, o governo federal não fez a cobrança do valor por meio da tomada de contas. Os motivos das irregularidades na prestação de contas vão desde o desvio da finalidade do projeto inicial até o não-cumprimento da contrapartida exigida pela União.
\end{abstract}

Todo gestor público é obrigado a prestar contas dos recursos recebidos, sob pena de aplicação de sanções previstas em lei e de comprometer o fluxo de recursos, mediante suspensão de transferências. Assim, ao termino da vigência do instrumento que efetuou a transferência de recursos, deve o responsável pela aplicação dos recursos adotar as medidas cabíveis com vistas à apresentação das contas. 
A não prestação de contas ou a aplicação inadequada dos recursos transferidos resulta na tomada de contas especial, sob a competência do Tribunal de Contas da União.

“A Tomada de Contas Especial é um processo devidamente formalizado, dotado de rito próprio, que objetiva apurar os fatos, identificar os responsáveis e quantificar o dano causado ao Erário, visando o seu imediato ressarcimento". (BRASIL, 2008b).

As diversas falhas e irregularidades encontradas nas fases do convênio em auditorias e fiscalizações realizadas pelo TCU apontaram como conseqüência, a necessidade de mudança na legislação dos convênios e a criação de uma nova forma de operacionalização dos mesmos.

Nessa perspectiva, o que esse estudo pretende abordar são os principais fatores que motivaram o governo federal a implantar um novo Sistema de Gestão dos Convênios, descrever os aspectos mais significativos da mudança ocorrida na lei, analisando as alterações nas fases de celebração, execução e prestação de contas e, finalmente, descrever o Portal de Convênios e seu Sistema de Gestão dos Convênios de forma a avaliar se a nova forma de operacionalização das transferências voluntárias vai trazer mecanismos viáveis para a auxiliar o Tribunal de Contas da União, no processo de tomada de contas especial.

\section{1- Formulação do problema de pesquisa}

Dados levantados durante a formulação do problema de pesquisa mostraram que o controle e a fiscalização das transferências voluntárias de recursos da União a Estados, Municípios e Entidades sem Fins Lucrativos, mediante convênios, têm sido objeto de discussão entre os órgãos controladores do Governo Federal, principalmente pelo aumento crescente desse tipo de transferência nos últimos anos.

Inúmeros casos de irregularidades encontradas nas transferências voluntárias mediante convênios têm despertado a atenção da Administração Pública e da sociedade, como por exemplo, o escândalo da máfia das ambulâncias, que desviou milhões de reais dos cofres públicos. Sobre algumas irregularidades encontradas nos convênios Brito e Valadão (2007) afirmam que:

\footnotetext{
Não foram poucas vezes em que tivemos de examinar convênios, para celebração ou aditamento, em que ficavam implícitos ou explícitos laços parentais ou afetivos entre os gestores e os partícipes, situações outras em que as entidades convenentes eram basicamente sustentadas pelo Erário e os salários dos empregados bem maiores que os vencimentos dos servidores estaduais, ainda outras hipóteses de ajustes em que, às vésperas de eleição, os conveniados eram apenas municípios cujos prefeitos integravam a mesma coligação partidária do governador de então.
}

Partindo destes revezes, a figura do convênio administrativo, tem sido, em muitos casos, uma vala aberta para irregularidades, que merecem ser coibidas enérgica e urgentemente. 
Tanto que, visando uma maior necessidade de controle e fiscalização do gasto público, o Tribunal de Contas da União propôs ao Ministério do Planejamento, através do Acórdão TCU 2066/2006 - Plenário, (BRASIL, 2006c) que elaborasse uma nova forma de operacionalização dos convênios, onde todas as fases do convênio ficassem registradas on-line, em sitio na internet, com possibilidade de acesso a toda população.

Em conseqüência à solicitação do TCU, foi elaborado o decreto 6.170 (BRASIL, 2007a), que instituiu o Portal de Convênios, marcando assim uma nova era para a operacionalização dos convênios e outros instrumentos de transferências de recursos.

Dessa forma, mudanças significativas sobre a forma de operacionalização dos convênios foram implantadas a partir de 2008 e o que esse estudo pretende realizar é a análise sobre a viabilidade do Portal de Convênios para o processo de tomada de contas especial realizado pelo Tribunal de Contas da União, relativo aos convênios firmados com Estados, Municípios e Entidade Privada sem Fins Lucrativos. 


\section{2 - Objetivos}

\subsection{1 - Objetivo geral}

O objetivo deste trabalho é realizar uma análise sobre a viabilidade de utilização do Portal de Convênios para auxiliar o processo de tomada de contas especial, realizado pelo Tribunal de Contas da União, referente às transferências voluntárias da União para Estados, Municípios e Entidades Privadas sem Fins Lucrativos, mediante convênios.

\subsection{2 - Objetivos específicos}

- Identificar os principais aspectos que motivaram o governo federal a implantar um Sistema de Gestão de Convênios.

- Descrever as mudanças significativas na legislação dos convênios e analisar as principais alterações nas fases de celebração, execução e prestação de contas.

- Descrever o Portal de Convênios, especificamente, o Sistema de Gestão dos Convênios, identificando os principais aspectos da nova forma de operacionalização das transferências voluntárias.

\section{3 - Justificativas}

O volume de transferências voluntárias da União para Estados, Municípios e entidades privadas sem fins lucrativos tem crescido significativamente nos últimos anos. A aplicação desses recursos tem sua importância para a erradicação da pobreza, diminuição das desigualdades sociais, acesso e aprimoramento do ensino público, enfim, em promoção de benefícios para a sociedade. Assim, esse tipo de operação necessita de um mecanismo de controle e fiscalização eficaz, de forma que os interesses públicos prevaleçam sobre quaisquer outros interesses.

Entretanto, os processos de controle e fiscalização não têm sido eficientes a ponto de conter os inúmeros casos de corrupção na aplicação de dinheiro público. Há facilidade de obtenção dos recursos públicos sem a preocupação com a prestação de contas, a legislação é frágil e as punições não são aplicadas de modo severo, causando uma sensação de impunidade pelos maus gestores. 
Inúmeras investigações vêm sendo realizadas no intuito de tentar coibir esse tipo de prática. Cabe ressaltar a instalação da CPMI das "ambulâncias", onde:

A análise do esquema de fraude e corrupção revelado pela operação "Sanguessuga", da Polícia Federal, apontou para um conjunto de causas relacionadas às deficiências nas etapas de celebração, execução, controle e fiscalização dos recursos transferidos voluntariamente pela União a Estados, Municípios e Entidades Privadas sem Fins Lucrativos. (BRASIL, 2006a).

O estudo e o aprofundamento dos mecanismos e procedimentos relacionados a cada uma dessas etapas possibilitou um diagnóstico, realizado pelo Congresso Nacional, acerca dos fatores que favoreceram comportamentos delituosos por parte dos agentes públicos e privados e culminou na formalização dos acórdãos 788 (BRASIL, 2006b) e 2066 (BRASIL, 2006c) do Tribunal de Contas da União, e no decreto 6.170 (BRASIL, 2007a) que, "dispõe sobre as normas relativas às transferências de recursos da União mediante convênios e contratos de repasse", o qual resultou na geração de um Portal na internet chamado Portal de Convênios.

A análise desse estudo vai se basear em que aspectos a nova operacionalização dos convênios, via Portal de Convênios, vai beneficiar e facilitar o processo de tomada de contas especial, realizado pelo órgão de controle externo do governo federal, o Tribunal de Contas da União.

A pesquisa do tema envolvendo o Tribunal de contas da União foi escolhida, pois o TCU é o órgão responsável pelo controle externo, e conforme estabelecido nos arts. 70 e 71 da Constituição Federal (BRASIL, 1988) tem a competência de fiscalizar os convênios desde a celebração até a prestação de contas, como também de impor sanções às irregularidades encontradas na gestão dos convênios, com o processo de tomada de contas especial, de forma a responsabilizar os responsáveis e recuperar os danos causados ao erário. E também por ter sido o TCU, um dos órgãos que realizou auditorias e fiscalizações com base nas diversas denúncias ocorridas na época da investigação da máfia das ambulâncias, e que deu origem aos acórdãos que fizeram com que uma nova forma de operacionalização dos convênios fosse estabelecida. 


\section{2 - Referencial Teórico}

Este item contém informações sobre como foi contextualizado o trabalho em termos de produção cientifica.

Primeiramente será apresentado o que são as Transferências de Recursos da União, as formas de transferências existentes, os aspectos legais, e as formas de operacionalização das mesmas. O próximo tópico trata dos Convênios, partindo de um histórico legal, evoluindo para o conceito, a origem, características básicas, finalidade e por fim serão detalhadas as quatro fases do Convênio.

Em seguida, será apresentado as formas de controle que a Administração Pública possui, os aspectos constitucionais que implantaram os controles interno e externo e suas competências, focando um pouco mais nas atribuições relativas ao Tribunal de Contas da União.

E por fim será descrito o processo de tomada de contas especial, contemplando as duas fases do processo.

\section{1 - Transferências de recursos da União}

O processo de transferência de recursos a Estados, Municípios e entidades privadas sem fins lucrativos, se dá com a realização de estudos junto às comunidades, no sentido de identificar as principais necessidades e carências das populações locais.

"Os repasses de recursos federais são efetuados por meio de três formas de transferências: transferências constitucionais, voluntárias e legais”. (BRASIL, 2008b).

As transferências constitucionais representam um percentual da arrecadação da União que são repassados aos Estados e Municípios por força de lei. Sobre o assunto em questão destaca Bastos Neto (2008, p.17):

As transferências constitucionais correspondem a parcelas de recursos arrecadados pelo Governo Federal e repassados aos Estados e Municípios por força de mandamento estabelecido em dispositivo da Constituição. Inserem-se nessa modalidade de transferência os recursos provenientes do Fundo de Participação dos Estados (FPE) e do Fundo de Participação dos Municípios (FPM).

Portanto, esse tipo de transferência é obrigatória e está balizada em dispositivo constitucional.

As transferências legais são regulamentadas em leis especificas. Sobre essa forma de transferência, Bastos Neto (2008, p.17-18) lembra que:

Essas leis determinam a forma de habilitação, transferência, aplicação de recursos e prestação de contas. Segundo ele há duas modalidades de transferências legais: 
a) as cuja aplicação dos recursos repassados não esta vinculada a fim especifico; Nesta situação o ente federado possui discricionariedade para definir a despesa correspondente ao recurso repassado pela União.

E o caso, por exemplo, dos royalties do petróleo, que conforme a Lei 7.435/85 são repassados aos Municípios, a titulo de indenização, $1 \%$ (um por cento) sobre o valor do óleo, do xisto betuminoso e do gás extraídos de suas respectivas áreas, onde se fizer a lavra do petróleo.

b) as cuja aplicação dos recursos repassados esta vinculada a um fim especifico.

Neste caso, a transferência legal tem um aspecto finalístico, os recursos são repassados para acorrer a uma despesa especifica. Nessa modalidade, o Estado e o Município devem se habilitar para receber recursos apenas uma vez e, a partir da habilitação, passam a ter o direito aos recursos federais, sem a necessidade de apresentação de documentos e tramitação de processos a cada pleito, como ocorre nas transferências voluntárias. Esse mecanismo tem sido utilizado, nos últimos anos, para repassar recursos aos Municípios em substituição aos convênios nos casos de ações de grande interesse para o governo.

Assim, as transferências legais podem ter seus recursos aplicados tanto discricionariamente, quando a aplicação é de livre escolha do ente federado, quanto vinculada a um fim específico, onde os recursos devem ser aplicados com uma finalidade definida.

Essa modalidade habilita os Estados e Municípios a receberem recursos, por uma vez, sem ter a obrigatoriedade de apresentar documentos, como ocorre nas transferências voluntárias, e, portanto, esse mecanismo tem sido utilizado nas ações de grande interesse para o governo.

“As descentralizações de recursos a Estados, Municípios, Distrito Federal e entidades privadas, destinadas à realização de ações cuja competência seja da União ou tenham sido delegadas aos entes Federados, com ônus para a União, são chamadas de transferências voluntárias”. (BASTOS NETO, 2008, p.17).

“As transferências voluntárias constituem, assim, um sistema de cooperação entre a União, entidades governamentais subnacionais e organizações não governamentais, para a execução de ações de interesse recíproco, financiadas com recursos do Orçamento Geral da União (OGU)". (BRASIL, 2008b).

Neste estudo serão abordadas as transferências voluntárias, que são definidas na Lei Complementar $\mathrm{n}^{\mathrm{o}} 101$ como "a entrega de recursos correntes ou de capital a outro ente da Federação, a titulo de cooperação, auxilio ou assistência financeira, que não decorra de determinação constitucional legal ou os destinados ao Sistema Único de Saúde”. (BRASIL, 2000b).

As transferências voluntárias podem ser operacionalizadas por meio de convênios ou contratos de repasse. Sobre os dois instrumentos para operacionalização das transferências voluntárias, Bastos Neto (2008, p.18) afirma: 
O contrato de repasse consiste em instrumento de transferência voluntária realizado por intermédio de instituições financeiras oficiais federais, que atuam como mandatárias da União.

O convênio pode ser definido como um instrumento qualquer que disciplina a transferência de recursos públicos e tenha como partícipe órgão da Administração Pública Federal direta, autárquica, fundacional, empresa pública ou sociedade de economia mista que estejam gerindo recursos dos orçamentos da União, visando à execução de programas de trabalho, projeto/atividade ou evento de interesse recíproco, em regime de mútua cooperação.

Conforme o autor, a diferença básica entre as duas formas de operacionalização das transferências é que no contrato de repasse deve haver o intermédio de uma instituição financeira. Neste estudo será tratado basicamente das transferências voluntárias mediante convênios.

A Lei de responsabilidade Fiscal, a Lei de Diretrizes Orçamentárias e a Legislação Federal dispõem que Estados, Distrito Federal e Municípios, para receberem transferências voluntárias, devem atender as seguintes condições:

1-Contas do exercício:

Enviar suas contas ao Poder Executivo Federal, nos prazos previstos, para consolidação nacional e por esfera de governo, relativas ao exercício anterior. Os Estados devem encaminhar suas contas até 31 de maio. Os municípios, até 30 de abril de cada ano, com copia para o Poder executivo do respectivo Estado.

2-Relatório da execução orçamentária:

Publicar o relatório resumido da execução orçamentária até 30 dias após o encerramento de cada bimestre.

3-Relatório de Gestão Fiscal:

Publicar o relatório de gestão fiscal até 30 dias após o encerramento de cada quadrimestre. E facultado aos Municípios com população inferior a 50 mil habitantes optar por divulgar o relatório de gestão fiscal semestralmente, até 30 dias após o encerramento do semestre.

4-Limites de gasto com pessoal:

Observar os limites de gasto com pessoal, verificados ao final de cada quadrimestre (caso os limites sejam ultrapassados, não havendo redução no prazo estabelecido e enquanto perdurar o excesso, o ente da Federação não poderá receber transferências voluntárias).

5-Regularidade na gestão fiscal:

Demonstrar a instituição, regulamentação e arrecadação de todos os tributos previstos nos artigos 155 e 156 da Constituição Federal.

6-Despesas com pessoal:

Não destinar os recursos ao pagamento de despesas com pessoal ativo, inativo ou pensionista.

7-Adimplência com a União:

Estar em dia com os pagamentos de tributos, empréstimos e financiamentos devidos a União.

8-Adimplência com outros convênios:

Estar adimplente com o dever de prestar contas no tocante a recursos anteriormente recebidos.

9-Limites constitucionais de aplicação em educação e saúde:

Cumprir os limites constitucionais de aplicação de recursos em educação e saúde.

10-Limites da divida pública:

Observar os limites das dividas consolidada e mobiliaria, das operações de credito, inclusive por antecipação de receita, de inscrição em restos a pagar e da despesa total com pessoal (o Estado, o Distrito Federal ou o Município ficara impedido de receber transferências voluntárias, se a respectiva divida consolidada ultrapassar o limite que a ela corresponde ao final de um quadrimestre). Da mesma forma, assim 
ocorrera uma vez vencido o prazo para retorno da divida a seu limite até o termino de três quadrimestres subseqüientes e enquanto perdurar o excesso.

11-Contrapartida:

Estabelecer previsão orçamentária de contrapartida compatível com a capacidade financeira do convenente e de acordo com o Índice de Desenvolvimento Humano (IDH), a qual poderá ser atendida por meio de recursos financeiros, ou de bens/serviços, se economicamente mensuráveis.

12-Cadin:

Comprovar a inexistência de pendências pecuniárias junto ao Cadastro Informativo de Créditos não Quitados do Setor Público Federal (Cadin).

13-Regularidade junto ao INSS e ao FGTS:

Apresentar Certificado de Regularidade Previdenciária (CRP) e a comprovação de regularidade quanto ao deposito das parcelas do Fundo de Garantia por Tempo de Serviço (FGTS). (BRASIL, 2008b).

Esse rol de condições não é exigido por acaso. Somente busca-se assegurar um mecanismo de controle dos gastos sociais e distribuição de encargos e responsabilidades entre os três níveis de governo mais adequado, já que são recursos públicos que estão sendo transferidos.

"Se os recursos são transferidos pelo governo federal, é mais do que razoável a prestação de contas de sua aplicação, não apenas para o poder central, mas para que o conjunto da sociedade saiba se os tributos pagos estão sendo bem aplicados". (GARCIA, 1995).

A descentralização da execução de políticas públicas exige coordenação, monitoramento e controle das ações por parte dos órgãos e entidades diretamente responsáveis pelos programas. Afirma Carvalho Neto (2007) que:

Esses órgãos e entidades não são meros executores de transferências orçamentárias, mas gestores de programas, cujos objetivos e metas devem zelar pelo cumprimento. O planejamento, nesse contexto, constitui elemento imprescindível para se fixar padrões de controle e aferição de resultados, sem o que, resta absolutamente comprometida a atuação dos órgãos que, por dever constitucional, velam pelo patrimônio público, como é o caso, dentre outros, do TCU, do Ministério Público, da Controladoria-Geral da União (CGU) e da Advocacia-Geral da União (AGU).

As condicionantes estabelecidas pressupõem, também, que todo o processo de realização das transferências deve ser pautado por atos e mecanismos que favoreçam seu questionamento quanto à adequação aos critérios de atuação pública, bem como oferecer garantia de informações, métodos, sistemas e processos fidedignos que permitam a atuação eficaz dos órgãos de controle do Estado e da própria sociedade, no exercício do controle social.

O que o texto afirma é que os gestores dos programas de governo são responsáveis por zelar pelo cumprimento dos objetivos e metas fixadas para executar a aplicação dos recursos, como também os órgãos de controle como o Ministério Público e Tribunal de Contas da União e advocacia Geral da União. Mas para auxiliar no controle do gasto, as transferências de recursos devem seguir critérios que busquem efetivar a atuação dos órgãos de controle do Estado. 


\section{2 - Convênios}

\subsection{1 - Histórico legal}

A regulamentação dos convênios é estabelecida por leis especificas, assim será mostrado neste tópico, a evolução das legislações aplicadas ao assunto e qual a aplicação vigente nos dias de hoje.

$\mathrm{O}$ art. 48 do Decreto $\mathrm{n}^{\mathrm{o}} 93.872$ (BRASIL, 1986), que foi recepcionado pela Constituição Federal, dispõe que "os serviços de interesses recíprocos, dos órgãos e entidades da Administração Federal, e de outras entidades públicas ou organizações particulares, poderão ser executados, sob o regime de mútua cooperação, mediante convênio".

O referido diploma normativo, em seu art. 49 afirma que:

Os convênios poderão ser utilizados como forma de descentralização das atividades da administração federal, através da qual se delegará a execução de programas federais de caráter nitidamente local, no todo ou em parte, aos órgãos estaduais ou municipais incumbidos de serviços correspondentes, e quando estejam devidamente aparelhados. (BRASIL, 1986).

A partir da Emenda Constitucional $\mathrm{n}^{\circ}$ 19, que implanta a chamada "Reforma Administrativa", surge disposição que altera o art. 241 da Constituição Federal, consignandolhe a seguinte redação:

A União, os Estados, o Distrito Federal e os Municípios disciplinarão por meio de lei os consórcios públicos e os convênios de cooperação entre os entes federados, autorizando a gestão associada de serviços públicos, bem como a transferência total ou parcial de encargos, serviços, pessoal e bens essenciais à continuidade dos serviços transferidos. (BRASIL, 1988).

Sobre esta disposição legal Miragem (2000) observa:

Esta disposição constitucional vem, em verdade, dispor expressamente sobre uma espécie de cooperação geral entre os entes federados, na gestão dos serviços públicos e transferência de encargos. Impõe, então, sejam disciplinados por lei, os acordos jurídicos próprios de cooperação, vinculando-os a um regime jurídico uniforme. A nosso sentir, a iniciativa que se pretende a partir desta norma constitucional é evidente. De um lado o fomento das relações de cooperação como meio de assegurar a eficiência administrativa. De outro, uma razoável uniformidade dos acordos de cooperação, que assegure sua adequação técnica do ponto de vista jurídico e administrativo. Propugna, igualmente, a descentralização da atuação administrativa, permitindo procedimento de transferência de encargos, serviços, pessoal e bens, num regime de ampla coordenação. A uniformidade do regime legal dos acordos jurídicos pertinentes, entretanto, deve ser observada modus in rebus. Isto porque não refere o dispositivo à regulamentação por lei específica, o que de certo modo dá oportunidade do estabelecimento de diversos regimes legais, tantos quantos forem os eventos e atividades disciplinados.

Partindo desse pressuposto, em primeiro lugar, é imprescindível se fixar os contornos jurídicos do instituto do convênio, pois há de haver uma adequação técnica sob o aspecto jurídico e administrativo, já que se propõe uma relação de cooperação e transferência de encargos na gestão dos serviços públicos. Entretanto, como o autor mesmo coloca, o 
dispositivo constitucional em nada se refere sobre uma regulamentação sobre os consórcios e convênios por lei específica.

De maneira bem mais clara e precisa, a Instrução Normativa $n^{\circ} 01$ da Secretaria do Tesouro Nacional, que é a norma que regulamenta os convênios, logo em seu art. $1^{\circ}$ afirma o seguinte:

\begin{abstract}
Art. $1^{\circ}$ A execução descentralizada de Programa de Trabalho a cargo de órgãos e entidades da Administração Pública Federal, Direta e Indireta, que envolva a transferência de recursos financeiros oriundos de dotações consignadas nos Orçamentos Fiscais e da Seguridade Social, objetivando a realização de programas de trabalho, projeto, atividade, ou de eventos com duração certa, será efetivada mediante a celebração de convênios ou destinação por Portaria Ministerial, nos termos desta Instrução Normativa, observada a legislação pertinente. (BRASIL, 1997).
\end{abstract}

Dessa forma, essa norma passou a reger as transferências de recursos da União, a Estados, Municípios e entidades privadas sem fins lucrativos.

Segundo Souza (2007) "os dois diplomas normativos efetivamente importantes para o administrador público, no que se refere aos convênios, são a Lei $n^{0}$ 8.666/93 e a IN/STN/01/97”. Esta última, apesar de ser mera norma infralegal, contém determinações próprias de leis de conteúdo material, tanto que é perfeitamente aceita pelo Tribunal de Contas da União.

Já a Lei 8.666/93 estabelece no art. 116 que, "é ela aplicável a convênios e outros acordos congêneres". (BRASIL, 1993).

Para Souza (2007) "no verdadeiro convênio inexiste perseguição de lucro, e os recursos financeiros empregados servem para cobertura dos custos necessários à operacionalização do acordo. Como os pactuantes já estão previamente ajustados para o fim comum a que se propõem, raramente será possível a competitividade que marca o processo licitatório". Conclui-se pela afirmação do autor que se torna incoerente a realização de licitação.

Conforme o autor, já que não há uma perseguição de lucro nos acordos firmado mediante convênios, não há de se ter um processo competitivo e por isso não há de existir um processo licitatório para se firmar convênios.

Os convênios celebrados até 14 de abril de 2008 sujeitam-se às disposições da IN/STN/01 (BRASIL, 1997), e suas alterações. A partir dessa data, as normas relativas às transferências de recursos da União mediante convênios, contratos de repasse e termos de cooperação são dispostas no decreto 6.170 (2007a) e alterações, acrescidos pelo decreto 6.497 (2008c) e na portaria interministerial $\mathrm{n}^{\circ} 127$ (2008a) do Ministério do Planejamento, Orçamento e Gestão, da Fazenda e do Controle e da Transparência, com aplicação supletiva 
da IN/STN/01 (BRASIL, 1997), naquilo que não for incompatível com os dispositivos do novo ordenamento inaugurado pelo decreto 6.170 (BRASIL, 2007a).

Dessa forma o decreto 6.170 (2007a) que "regulamenta os convênios, contratos de repasse e termos de cooperação celebrados pelos órgãos e entidades da Administração Pública Federal com órgãos ou entidades públicas ou privadas sem fins lucrativos" estabelece que:

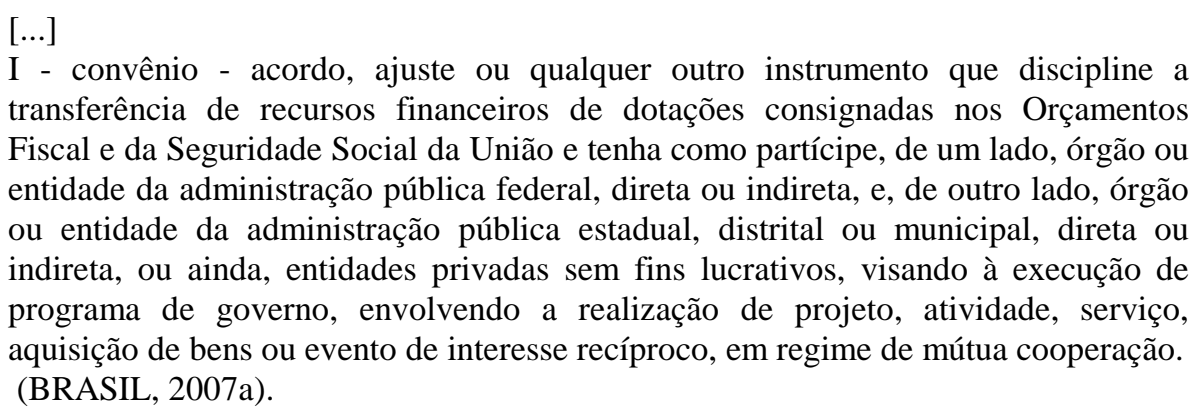

O referido decreto também instituiu o sistema de Gestão de Convênios e Contratos de Repasse (SICONV) e o Portal de Convênios do Governo Federal (www.convenios.gov.br).

Sobre o SICONV a portaria $\mathrm{n}^{\circ} 127$ estabelece que:

\begin{abstract}
Art. $3^{\circ}$ Os atos e os procedimentos relativos à formalização, execução, acompanhamento, prestação de contas e informações acerca de tomada de contas especial dos convênios, contratos de repasse e termos de parceria serão realizados no Sistema de Gestão de Convênios e Contratos de Repasse - SICONV, aberto à consulta pública, por meio do Portal dos Convênios. (BRASIL, 2008a).
\end{abstract}

Fica estabelecida assim a nova forma de operacionalização dos convênios, via Portal de Convênios.

\title{
2.2.2 - Conceitos
}

"Convênio, vocábulo originário do latim"cum + venire", significa ação conjunta de aproximação, quase sinônimo de acordo - que sugere mais a idéia de superação de um conflito ou a preocupação de preveni-lo —, e visa a construir as bases de uma colaboração mútua”. (SA; RABELLO, 1987).

O convênio disciplina a transferência de recursos públicos e, portanto:

Convênio é o acordo, ajuste ou qualquer outro instrumento que discipline a transferência de recursos financeiros dos Orçamentos da União visando à execução de programa de governo, envolvendo a realização de projeto, atividade, serviço, aquisição de bens ou evento de interesse recíproco, em regime de mútua cooperação, e tenha como participes, de um lado, órgão da administração pública federal direta, autarquias, fundações públicas, empresas públicas ou sociedades de economia mista, e, de outro, órgão ou entidade da administração pública estadual, distrital ou municipal, direta ou indireta, ou ainda, privadas sem fins lucrativos. (BRASIL, 2008b). 
Assim, pode-se dizer que é uma forma de ajuste entre o poder público e entidades públicas ou privadas para a realização de objetivos de interesse comum, mediante mútua cooperação.

Sobre o surgimento dos convênios comenta Meireles (2003, p.386-387):

A ampliação das funções estatais, a complexidade e o custo das obras públicas vêm abalando, dia a dia, os fundamentos da Administração Clássica, exigindo novas formas e meios de prestação de serviços afetos ao Estado.

Evoluímos, cronologicamente, dos serviços públicos centralizados para os serviços delegados a particulares, destes passamos aos serviços outorgados a autarquias; daqui defletimos para os serviços traspassados a fundações e empresas estatais e, finalmente, chegamos aos serviços de interesse recíproco de entidades públicas e organizações particulares realizados em mútua cooperação, sob a forma de convênios e consórcios administrativos. E assim se faz porque, em muitos casos, já não basta a só modificação instrumental da prestação do serviço na área de responsabilidade de uma Administração. Necessárias se tornam a sua ampliação territorial e a conjugação de recursos técnicos e financeiros de outros interessados na sua realização. Desse modo conseguem-se serviços de alto custo que jamais estariam ao alcance de uma Administração menos abastada. Daí o surgimento dos convênios e consórcios administrativos, como solução para tais situações.

Conclui-se pelo texto, que com a variedade de serviços delegados pela Administração Pública, menor se torna os custos desses serviços para o Governo Federal, onde com a realização de cooperação mútua se tem uma descentralização dos custos, tornando mais amplo as áreas de atuação do Governo e proporcionando um maior alcance dos atendimentos prestados pela Administração Pública.

Como os convênios são acordos de vontades entre as partes, podemos afirmar que a possibilidade de tais acordos é ampla, podendo ser realizado entre quaisquer pessoas ou organizações públicas ou particulares que disponham de meios para realizar os objetivos comuns, de interesse recíproco dos participes.

A característica básica do convênio é a ausência de remuneração de qualquer de seus signatários. Segundo Bastos Neto (2008, p.24):

Como se trata de uma parceria, de uma soma de esforços para se atingir um objetivo comum, tradicionalmente, se convenciona que um dos participes se incumbe de fazer a transferência de soma de recursos financeiros - destinados a custear despesas relacionadas com o objeto pretendido -, enquanto ao outro se atribuem tarefas, como a execução propriamente dita do objeto do convênio ou outra que venha a ser convencionada, além de uma parcela de recursos, que podem ser financeiros, humanos, em bens e serviços - desde que economicamente mensuráveis -, chamada contrapartida.

Dessa forma, há de haver a colaboração das duas partes interessadas, onde uma transfere o recurso e a outra executa o programa, dando como garantia a contrapartida que pode ser que uma entidade púbica acorda com outras entidades públicas ou privadas, na realização de obras ou serviços públicos de competência da primeira, enquanto que nos consórcios a competência é de todas. 
A disposição que altera o art. 241 da Constituição Federal, consignando-lhe a seguinte redação define:

A União, os Estados, o Distrito Federal e os Municípios disciplinarão por meio de lei os consórcios públicos e os convênios de cooperação entre os entes federados, autorizando a gestão associada de serviços públicos, bem como a transferência total ou parcial de encargos, serviços, pessoal e bens essenciais à continuidade dos serviços transferidos. (BRASIL, 1988).

Pelo texto constitucional pressupõe-se que deverá haver uma forma de cooperação entre os entes federados, na gestão dos serviços públicos e a descentralização da atuação administrativa, com a transferência de encargos, serviços, pessoal e bens, num regime de ampla coordenação. Dispõe que sejam disciplinados por lei, os acordos de cooperação, vinculando-os a um regime jurídico uniforme, de forma que esses acordos sirvam como um meio de assegurar a eficiência da Administração no trato dos interesses coletivos.

\subsection{3 - Fases do Convênio}

Os convênios envolvem basicamente quatro fases: preposição, celebração, execução e prestação de contas. De acordo com o decreto 6.170 (BRASIL, 2007a), todas as informações pertinentes às fases do convênio, deverão estar registradas no Sistema de Gestão de Convênios e Contratos de Repasse - SICONV, o qual estará acessível a toda população, em sítio específico na internet, chamado Portal de Convênios, a partir de janeiro de 2008.

\subsubsection{1 - Proposição}

O processo de transferência de recursos a Estados e Municípios se dá com a realização de estudos junto às comunidades, no sentido de identificar as principais necessidades e carências das populações locais.

"Na escolha das prioridades deve ser levado em conta o segmento a ser atingido, o impacto do projeto, sua abrangência, o custo-benefício e qual a contrapartida poderá ser destinada ao projeto". (BRASIL, 2008b).

A partir daí, cabe ao interessado buscar nos órgãos e entidades da Administração Pública, os recursos necessários para a execução do projeto a partir do conhecimento dos programas de cada órgão e cadastramento das propostas de trabalho relativas ao programa de interesse. 
Existe um único pré-requisito básico para a celebração de convênios, dessa maneira Bastos Neto (2008, p.35) afirma:

A previsão de dotação orçamentária no Orçamento Geral do poder concedente. Os recursos utilizados na celebração de Convênios são originários das dotações orçamentárias consignadas nos orçamentos fiscal e da seguridade social para os órgãos e entidades do Governo Federal, inclusive as decorrentes de emendas parlamentares.

Assim, as proposições de convênios que tiverem suas propostas de acordo com prioridades estabelecidas pelo Governo Federal devem ter maiores chances de serem contempladas com os recursos provenientes do orçamento.

De acordo com a nova legislação aplicada aos convênios, para propor a celebração de um convênio, apresentando sua proposta de trabalho, o interessado deverá primeiramente se credenciar. Sobre esse aspecto a portaria $\mathrm{n}^{\circ} 127$ afirma:

Art. 14. O credenciamento será realizado diretamente no SICONV e conterá, no mínimo, as seguintes informações:

I - nome, endereço da sede, endereço eletrônico e número de inscrição no Cadastro Nacional de Pessoas Jurídicas - CNPJ, bem como endereço residencial do responsável que assinará o instrumento, quando se tratar de instituições públicas; e II - razão social, endereço, endereço eletrônico, número de inscrição no Cadastro Nacional de Pessoas Jurídicas - CNPJ, transcrição do objeto social da entidade atualizado, relação nominal atualizada dos dirigentes da entidade, com endereço, número e órgão expedidor da carteira de identidade e CPF de cada um deles, quando se tratar das entidades privadas sem fins lucrativos. (BRASIL, 2008a).

“Após o credenciamento, o interessado deverá providenciar o cadastramento, no órgão ou entidade concedente ou nas unidades cadastradoras do SICAF (sistema de cadastramento unificado de fornecedores federais) que terá validade de um ano". (BRASIL, 2008b).

Um outro aspecto que deve ser considerado quando da proposição de convênios é a contrapartida.

"Contrapartida é a parcela de colaboração financeira do convenente para a execução do objeto do convênio". (BRASIL, 2008b).

A edição da IN/STN 04 (BRASIL, 2007b) excluiu a possibilidade de contrapartida em bens e serviços economicamente mensuráveis na celebração de convênios com entes públicos ou privados sem fins lucrativos. No entanto, o decreto 6.170 (BRASIL, 2007a) autoriza a contrapartida em bens economicamente mensuráveis que constará do convênio cláusula que indique a forma de aferição da contrapartida.

Os limites de contrapartida e as hipóteses de redução são fixados nas Leis de Diretrizes Orçamentárias (LDO). Para 2008 esses limites foram os seguintes: 


\begin{tabular}{|c|c|}
\hline No caso de Municípios: & \\
\hline Limites (Mínimo e Maximo) * & Situações \\
\hline $3 \%$ (três por cento) e $5 \%$ (cinco por cento) & $\begin{array}{l}\text { para municípios com ate } 50.000 \text { (cinqüenta mil) } \\
\text { habitantes. }\end{array}$ \\
\hline $5 \%$ (cinco por cento) e $10 \%$ (dez por cento) & $\begin{array}{l}\text { para municípios acima de } 50.000 \text { (cinqüenta } \\
\text { mil) habitantes localizados nas áreas prioritárias } \\
\text { definidas no âmbito da Política Nacional de } \\
\text { Desenvolvimento Regional (PNDR), nas áreas } \\
\text { da Superintendência do Desenvolvimento do } \\
\text { Nordeste (SUDENE) e da Superintendência do } \\
\text { Desenvolvimento da Amazônia (Sudam) e na } \\
\text { Região Centro-Oeste. }\end{array}$ \\
\hline $10 \%$ (dez por cento) e $40 \%$ (quarenta por cento) & Para os demais \\
\hline No caso dos Estados e Distrito Federal: & \\
\hline Limites (Mínimo e Maximo)* & Situações \\
\hline $10 \%$ (dez por cento) e $20 \%$ (vinte por cento) & $\begin{array}{l}\text { se localizados nas áreas prioritárias } \\
\text { definidas no âmbito do PNDR, nas } \\
\text { áreas da SUDENE e Sudam e na } \\
\text { Região Centro-Oeste. }\end{array}$ \\
\hline $20 \%$ (vinte por cento) e $40 \%$ (quarenta por cento) & Para os demais. \\
\hline
\end{tabular}

Quadro 1: Limites de Contrapartida Municípios, Estados e Distrito Federal

*As hipóteses de redução estão previstas no art. 43 da LDO 2008.

Fonte: Tribunal de Contas da União. Brasília (2008).

O interessado também deverá apresentar sua proposta de trabalho no SICONV, em conformidade com os programas e diretrizes disponíveis no sistema. Partindo desse pressuposto:

Uma vez aceita, a proposta passa a ser denominada Plano de Trabalho, que é o documento por meio do qual o gestor define como o objeto do convênio será realizado. O plano de trabalho será analisado quanto a sua viabilidade e adequação aos objetivos do programa governamental e, no caso das entidades privadas sem fins lucrativos, será avaliada sua qualificação técnica e capacidade operacional para gestão do instrumento, de acordo com critérios estabelecidos pelo órgão ou entidade repassador do recurso. (BRASIL, 2008b).

Uma vez apresentada a proposta, esta passa a ser denominada plano de trabalho, que é o documento que deverá conter as informações sobre a execução do convênio e que será analisado e aprovado pelo órgão concedente. Dessa maneira a portaria $\mathrm{n}^{\mathrm{o}} 127$ dispõe sobre o plano de trabalho da seguinte forma:

Art. 21. O Plano de Trabalho, que será avaliado após a efetivação do cadastro do proponente, conterá, no mínimo:

I - justificativa para a celebração do instrumento;

II - descrição completa do objeto a ser executado;

III - descrição das metas a serem atingidas;

IV - definição das etapas ou fases da execução;

V - cronograma de execução do objeto e cronograma de desembolso; e 
VI - plano de aplicação dos recursos a serem desembolsados pelo concedente e da contrapartida financeira do proponente, se for o caso. (BRASIL, 2008a).

Pode-se dizer que o plano de trabalho deve ser consistente e conter os aspectos necessários para atender as necessidades das comunidades, onde as informações devem ter um nível de detalhamento e exatidão que realmente caracterize a aplicação dos recursos almejados de forma a não incorrer em falhas e provocar a não celebração do convênio.

O gestor deve atentar para a fidedignidade e exatidão das informações contidas no plano de trabalho. Qualquer falha, inexatidão no projeto ou falsidade de informações implicara a não celebração do convênio, motivo pelo qual exigências como previsão de contrapartida, correta contextualização da situação da necessidade, preenchimento adequado dos formulários específicos, apresentação de plano de trabalho consistente e completo devem ser observadas com bastante atenção.

A exatidão das informações do plano de trabalho tem repercussão, também, na execução do convênio e na respectiva prestação de contas. A fiscalização dos órgãos federais de controle baseia-se nas informações do plano de trabalho para fixar critérios de avaliação do alcance das metas propostas. Subestimar ou superestimar as metas, os custos ou o cronograma de execução do objeto do convênio poderá trazer sérias conseqüências para o gestor do convênio. (BRASIL, 2008b).

Portanto, o plano de trabalho é o instrumento que conterá todas as atividades, custos e metas que serão atingidas pelo convênio e que irá balizar a aprovação da celebração do convênio, como também auxiliar todo o acompanhamento e fiscalização das ações de execução do objeto do convênio. Daí a importância da correta contextualização e completude desse documento.

\subsubsection{2 - Celebração}

Para a celebração de convênios com a União, o decreto 6.170 (BRASIL, 2007a) estabelece alguns pré-requisitos. A portaria n 127 (BRASIL, 2008a) estabelece em que "as condições para a celebração de convênios e contratos de repasse, a serem cumpridas pelos convenentes ou contratados, devem seguir o previsto na Lei Complementar $n^{\circ} 101$ (BRASIL, 2000b), na Lei de Diretrizes Orçamentárias e na legislação federal”.

"Todos os documentos de natureza fiscal ou cadastros de inadimplemento serão exigidos como requisitos e exigências para a celebração de convênios e serão confirmados mediante consultas aos cadastros de órgãos e entidades componentes dos sistemas de controle da Administração Pública”. (BASTOS NETO, 2008, p.37).

A LRF, a LDO e a legislação federal dispõem que Estados, Municípios e Distrito Federal, para receberem recursos mediante transferências voluntárias devem atender as seguintes condições, descritas resumidamente na figura abaixo: 


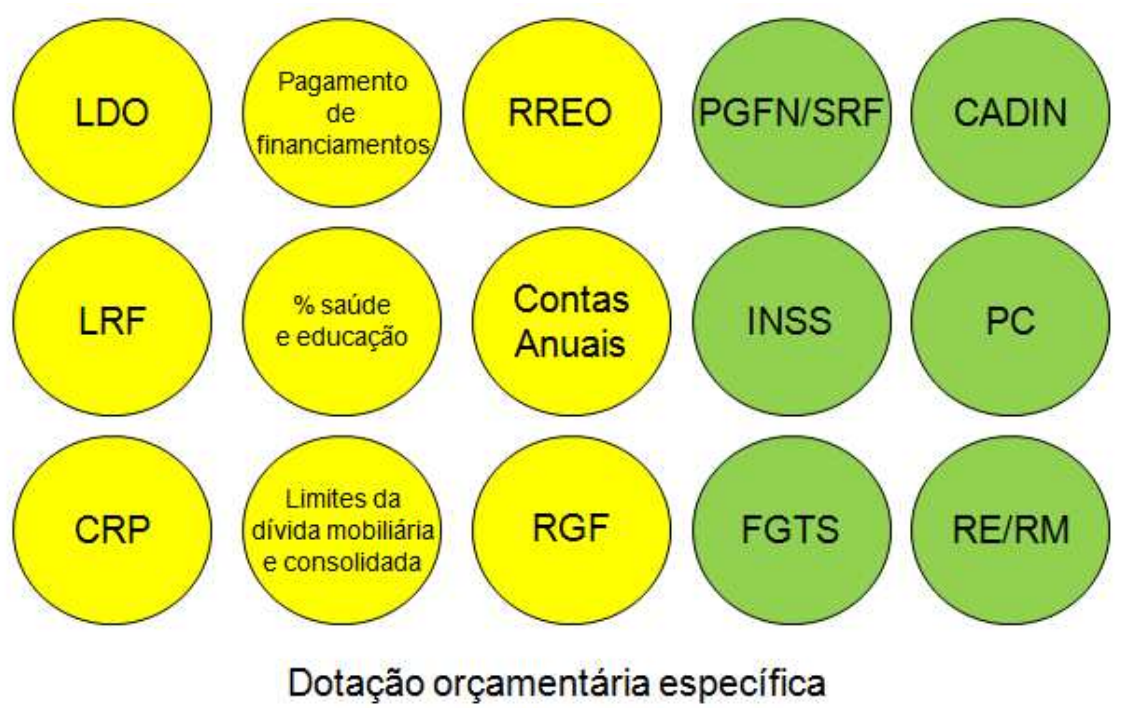

Figura 1: Requisitos para celebração de convênios

Fonte: Bastos Neto. In: Semana Orçamentária. Brasília, DF, 2008.

A portaria n 127 (BRASIL, 2008a) estabelece que "a avaliação do convênio proposto é feita pela área técnica responsável pelo programa, sendo de sua responsabilidade a emissão de Parecer Técnico". Quando da emissão de tal parecer, devem ser especialmente considerados os seguintes aspectos, dentre outros:

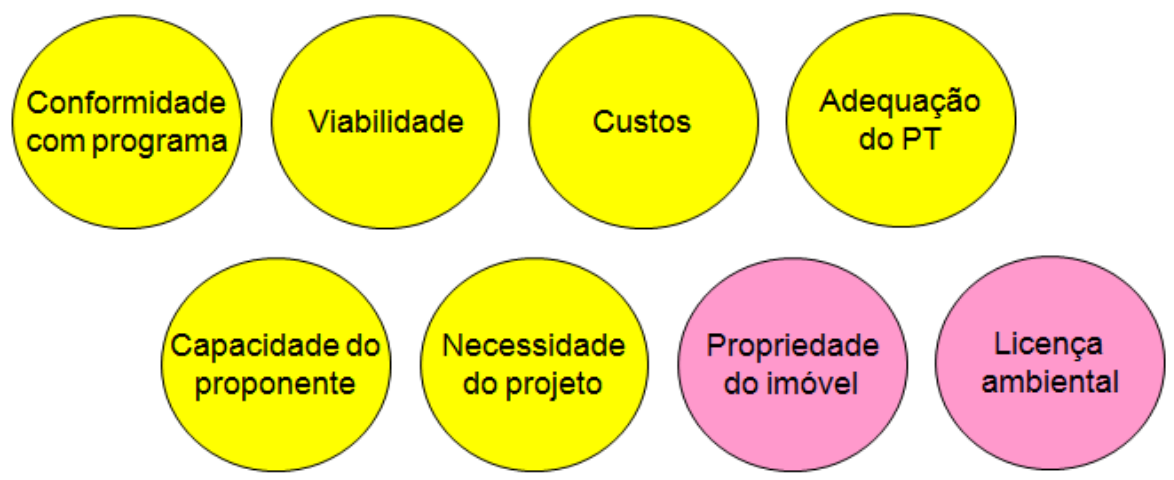

Figura 2: Aspectos avaliados no parecer técnico

Fonte: Bastos Neto. In: Semana Orçamentária. Brasília, DF, 2008.

Dessa forma, é de responsabilidade do concedente a análise e avaliação das propostas, devendo o parecer técnico seguir os aspectos citados na figura para se basear e dar o parecer favorável ou não a proposta.

Constatada alguma irregularidade ou imprecisão no Plano de Trabalho, o concedente comunicará o fato ao proponente, estipulando prazo de até 15 dias úteis para a regularização ou promoção das correções. A ausência da manifestação do convenente no prazo estipulado implicará a desistência no prosseguimento do processo. (BRASIL, 2008b). 
Sobre um outro foco, quando da celebração, o TCU recomendou à Secretaria do Tesouro Nacional que disciplinasse a obrigatoriedade de os órgãos/entidades concedentes estabelecerem critérios objetivamente aferíveis e transparentes para escolha das entidades privadas que receberão recursos por meio de convênios e outros instrumentos jurídicos utilizados para transferir recursos federais, levando-se em consideração a determinação contida no item 9.4 do Acórdão nº 1.777/2005-TCU-Plenário:

Determinar ao Ministério do Planejamento, Orçamento e Gestão e à Casa Civil da Presidência da República que avaliem a inclusão em normativo próprio de dispositivo que obrigue a aplicação do critério de seleção de Oscip previsto no art. 23 do Decreto n. ${ }^{\circ}$ 3.100/99 em toda e qualquer situação. (BRASIL, 2005).

A celebração de convênios e contratos de repasse nem sempre é permitida. As hipóteses de vedação estão declaradas na portaria $n^{\circ} 127$ :
Art. $6[\ldots]$
I - com órgãos e entidades da administração pública direta e indireta dos Estados, Distrito Federal e Municípios cujo valor seja inferior a R\$ 100.000,00 (cem mil reais);
II - com entidades privadas sem fins lucrativos que tenham como dirigentes, proprietários ou controladores:
a) membros dos Poderes Executivo, Legislativo, Judiciário, do Ministério Público e do Tribunal de Contas da União, bem como seus respectivos cônjuges, companheiros, e parentes em linha reta, colateral ou por afinidade até o $2^{\circ}$ grau; e b) servidor público inculado ao órgão ou entidade concedente, bem como seus respectivos cônjuges, companheiros, e parentes em linha reta, colateral ou por afinidade até o $2^{\circ}$ grau;
III - entre órgãos e entidades da Administração Pública federal, caso em que deverá ser firmado termo de cooperação;
IV - com órgão ou entidade, de direito público ou privado, que esteja em mora, inadimplente com outros convênios ou contratos de repasse celebrados com órgãos ou entidades da Administração Pública Federal, ou irregular em qualquer das exigências desta Portaria;
$\mathrm{V}$ - com pessoas físicas ou entidades privadas com fins lucrativos;
VI - visando à realização de serviços ou execução de obras a serem custeadas, ainda que apenas parcialmente, com recursos externos sem a prévia contratação da operação de crédito externo;
VII - com entidades públicas ou privadas cujo objeto social não se relacione às características do programa ou que não disponham de condições técnicas para executar o convênio ou contrato de repasse; VIII - com Estados, Distrito Federal ou Municípios, caso a soma das despesas de caráter continuado derivadas do conjunto das parcerias público-privadas já contratadas por esses entes tenham excedido, no ano anterior, a $1 \%$ (um por cento) da receita corrente líquida do exercício ou se as despesas anuais dos contratos vigentes nos 10 (dez) anos subseqüentes excederem a $1 \%$ (um por cento) da receita corrente líquida projetada para os respectivos exercícios, conforme disposto no art. 28 da Lei $\mathrm{n}^{\circ} 11.079$, de 30 de dezembro de 2004. (BRASIL, 2008a).

Portanto, as vedações impostas, tentam disciplinar com maior rigor as condições para celebração de convênios com a União de forma a auxiliar os órgãos de controle e inibir práticas fraudulentas. 


\subsubsection{3 - Execução}

O convênio deverá ser executado fielmente pelas partes, sendo observados o planejamento estabelecido no plano de trabalho aprovado e as normas de Administração Orçamentária e Financeira da Administração Pública Federal.

Falhas e irregularidades nesta fase podem comprometer as contas que serão apresentadas ao órgão concedente, sendo assim:

É muito freqüente o convenente perceber, ao receber os recursos, que o objeto previsto não poderá ser executado nos termos propostos no instrumento do convênio. Também acontece de o objeto proposto não ser mais considerado prioritário para o Município, tendo em vista o tempo decorrido entre a apresentação da proposta e a liberação dos recursos. Em ambos os casos é comum o gestor utilizar os recursos de maneira diferente daquela prevista no instrumento do convênio, sem fazer qualquer consulta ao órgão concedente. Esse procedimento - utilização de recursos em desacordo com a clausulas de convênio - é considerado falha de natureza grave e normalmente conduz ao julgamento pela irregularidade das contas apresentadas e a inclusão do nome do responsável no cadastro de contas irregulares do TCU, para remessa ao Ministério Público Eleitoral. (BRASIL, 2008b).

Portanto, as liberações de recursos devem seguir a procedimentos rígidos, pois se trata de dinheiro público que deve ser aplicado em estrita observância ao que objeto do convênio descrito no plano de trabalho.

A gestão financeira tem importância fundamental na execução do convênio. Para isso a portaria $\mathrm{n}^{\mathrm{o}} 127$ regulamenta que a liberação dos recursos deve estar em conformidade com o cronograma de desembolso estabelecido no plano de trabalho e determina:

\footnotetext{
Art.42 [...]

$\S 1^{\circ}$ Os recursos serão depositados e geridos na conta bancária específica do convênio ou do contrato de repasse exclusivamente em instituições financeiras controladas pela União e, enquanto não empregados na sua finalidade, serão obrigatoriamente aplicados:

I - em caderneta de poupança de instituição financeira pública federal, se a previsão de seu uso for igual ou superior a um mês; e

II - em fundo de aplicação financeira de curto prazo, ou operação de mercado aberto lastreada em título da dívida pública, quando sua utilização estiver prevista para prazos menores;

$\S 2^{\circ}$ Os rendimentos das aplicações financeiras serão obrigatoriamente aplicados no objeto do convênio ou do contrato de repasse, estando sujeitos às mesmas condições de prestação de contas exigidas para os recursos transferidos.

$\S 3^{\circ}$ As receitas oriundas dos rendimentos da aplicação no mercado financeiro não poderão ser computadas como contrapartida devida pelo convenente ou contratado. (BRASIL, 2008a).
}

Em hipótese alguma os recursos podem ser transferidos para movimentação em outras contas do convenente ou gerenciados recursos de diversos convênios em uma mesma conta e somente podem ser utilizados para pagamento de despesas constantes do plano de trabalho ou para aplicação no mercado financeiro, mas os rendimentos sempre serão aplicados no objeto do convênio e não podem ser considerados como contrapartida. 
"Os pagamentos devem seguir todos os estágios de pagamento de despesas na Administração Pública: empenho, liquidação e pagamento". (BRASIL, 1964).

O decreto 6.170 (BRASIL, 2007a) tornou obrigatório que os pagamentos sejam feitos por via bancária, isto é, não são aceitos pagamentos em espécie ou por meio de cheque nominal, saque de dinheiro e etc.

Dessa forma, tem-se o conhecimento de toda a movimentação financeira, desde a transferência do recurso para os Estados, Municípios e Entidades Privadas sem Fins Lucrativos, até o pagamento, que somente poderá ser realizado por via bancaria, com identificação do beneficiário final.

Existem duas exceções a essa regra, quais sejam:

\begin{abstract}
Art. $50[\ldots]$
$\S 4^{\circ}$ Excepcionalmente, mediante mecanismo que permita a identificação pelo banco, poderá ser realizado uma única vez no decorrer da vigência do instrumento o pagamento a pessoa física que não possua conta bancária, observado o limite de $\mathrm{R} \$$ 800,00 (oitocentos reais) por fornecedor ou prestador de serviço.

$\S 5^{\circ}$ Desde que previamente definido no instrumento e justificado pela autoridade máxima do concedente ou contratante, consideradas as peculiaridades do convênio e o local onde será executado, o convenente ou contratado disporá de valor a ser repassado para realização de despesas de pequeno vulto, não incidindo o disposto no inciso II, do $\S 2^{\circ}$, devendo o convenente ou contratado registrar, no SICONV, o beneficiário final do pagamento, conforme dispõe o $\S 3^{\circ}$. (BRASIL, 2007a).
\end{abstract}

Ainda de acordo com a legislação, não podem ser antecipados pagamentos a fornecedores de bens e serviços, salvo em casos admitidos em lei. E todos os lançamentos a débito, em conta corrente, devem corresponder a um comprovante de sua regular liquidação, emitido pelo beneficiário / fornecedor (empenho, nota fiscal, recibo, copia de cheque).

"Se concretizada, a improbidade pode ter como conseqüência a glosa dos valores e a sua devolução aos cofres públicos”. (BRASIL, 2007a).

Nesta fase, normalmente, ocorrem as ações de fiscalização dos órgãos federais de controle e suas conclusões servem de respaldo a avaliação das contas.

A portaria no 127 (BRASIL, 2008a) estabelece que a "execução será acompanhada e fiscalizada de forma a garantir a regularidade dos atos praticados e a plena execução do objeto, respondendo o convenente ou contratado pelos danos causados a terceiros, decorrentes de culpa ou dolo na execução do convênio, contrato, acordo, ajuste ou instrumento congênere".

Portanto, tem-se que a legislação previu que o controle deve acompanhar toda a vida do convênio, desde a celebração até a prestação de contas final e toda a fiscalização é necessária para que se garanta a regular aplicação dos recursos públicos. 


\subsubsection{1 - Fiscalização de convênios}

No caso de convênios celebrados com a União, existem três agentes fiscalizadores: o Órgão Concedente, a Controladoria Geral da União (CGU), e o Tribunal de Contas da União (TCU). Além desses agentes existe o órgão fiscalizado. Dessa forma Bastos Neto (2008, p.119) afirma que:

Dentro do prazo regulamentar de execução / prestação de contas do instrumento, a função gerencial / fiscalizadora deve ser exercitada pelos órgãos / entidades concedentes dos recursos, ficando assegurado aos seus agentes qualificados o poder discricionário de reorientar ações e de aceitar justificativas plausíveis com relação às eventuais disfunções havidas na execução.

Conforme o autor, a fiscalização do convênio, é de responsabilidade também do órgão concedente, transferidor dos recursos, que tem a prerrogativa de atuar discricionariamente, de forma a orientar as ações e julgar as justificativas para eventuais distorções. Portanto, a atuação conjunta do órgão concedente, no acompanhamento das ações é de primordial importância para a regularidade do convênio.

A Constituição Federal (BRASIL, 1988) e Lei Orgânica do Tribunal de Contas da União (BRASIL, 1992) "estabelecem que compete ao TCU fiscalizar a aplicação de recursos repassados pela União, mediante convênio, acordo, ajuste ou outros instrumentos congêneres, a Estados, Municípios, e ao Distrito Federal”.

Todas as fases dos convênios podem ser objeto de fiscalização do TCU. Celebração, formalização, execução e prestação de contas. A função fiscalizadora do TCU é deflagrada mediante solicitação do Congresso Nacional e de seus casas e por iniciativa própria, selecionando previamente os convênios com base em bancos de dados informatizados. Pode também ocorrer em razão de denuncias de terceiros, noticias de jornal, matérias vinculadas na televisão e representações apresentadas por autoridades, pelo controle interno federal ou pelos próprios servidores do Tribunal. (BRASIL, 2008b).

Portanto, o TCU tem a prerrogativa de fiscalizar os convênios em todas as suas fases e pode atuar também mediante denúncias, notícias e matérias da mídia, como também por indicação do controle interno.

"A fiscalização das transferências voluntárias da União compete também ao Poder Executivo, por intermédio da Secretaria Federal de Controle Interno, órgão da Controladoria Geral da União (CGU)”. (BRASIL, 2008b).

Sobre o papel da CGU, Bastos Neto (2008, p.120) lembra que "compete a Controlaria Geral da União, com relação às transferências voluntárias a entidades de direito privado, a avaliação de forma amostral, do objeto avencado, uma vez que o foco das CGUs esta nos resultados da ação governamental”. 
Sendo assim, a CGU também deve ter um papel presente na fiscalização dos convênios, onde de forma amostral possa averiguar a regularidade no cumprimento do objeto pactuado.

Segundo a portaria no 127 (BRASIL, 2008a) "é clausula obrigatória, em qualquer convênio, que os servidores do Sistema de Controle Interno ao qual seja subordinado o concedente, terão livre acesso, a qualquer tempo e lugar a todos os atos e fatos relacionados direta ou indiretamente com o Convênio, quando em missão de fiscalização e auditoria”.

Portanto, mais uma vez a legislação resguarda e firma a importância do controle das ações estabelecidas pelo convênio.

Bastos Neto (2008, p.120) explicita que "o Controle Interno do Executivo Federal, nos seus trabalhos de fiscalização e auditoria, verificará se o objeto pactuado foi executado, obedecendo aos respectivos: projeto e Plano de Trabalho".

Em suma, a importância da fiscalização do repasse de recursos pela União, vai ao encontro do cumprimento dos princípios básicos da Administração Pública, buscando garantir a eficácia na aplicação do dinheiro público. A presença dos órgãos fiscalizadores faz com que se iniba a má aplicação dos recursos públicos durante as fases do convênio, ocasionada muitas vezes por uma gestão ineficaz.

\subsubsection{4 - Prestação de Contas}

Todo gestor público é obrigado a prestar contas dos recursos recebidos, sob pena de aplicação de sanções previstas em lei e de comprometer o fluxo de recursos, mediante suspensão de transferências. Assim, ao termino da vigência do instrumento que efetuou a transferência de recursos, deve o responsável pela aplicação dos recursos adotar as medidas cabíveis com vistas à apresentação das contas.

De acordo com determinação constitucional (BRASIL, 1988), “devem prestar contas qualquer pessoa física ou jurídica, pública ou privada, que, utilize, arrecade, guarde, gerencie ou administre dinheiros, bens e valores públicos ou pelos quais a União responda”.

O texto constitucional é bem claro no sentido de que, todos que manejam um dinheiro ou bem público tem a obrigação de demonstrar a utilização e aplicabilidade dada ao recurso recebido.

Bastos Neto (2008, p.125) lembra também que, "prestarão contas, as mesmas pessoas, caso assumam obrigações de natureza pecuniária em nome da União". 
A obrigatoriedade de prestação de contas de recursos recebidos da União é mandamento constitucional inquestionável, não podendo ser dispensada por vontade das partes.

Sobre o assunto, o parecer do Ministério Público, relativamente ao Acórdão 625/05 TCU declara:

\begin{abstract}
A não comprovação da lisura no trato de recursos públicos recebidos autoriza a presunção de irregularidade na sua aplicação. Ônus da prova e da idoneidade no emprego dos recursos federais, no âmbito do administrativo, recai sobre o gestor (convenente), obrigando-se este a comprovar que os mesmos foram regularmente aplicados quando da realização do interesse público. (BRASIL, 2005).
\end{abstract}

Entende-se pelo acórdão que a obrigação legal é a prestação de contas e, portanto, a não comprovação da lisura na utilização dos recursos recebidos, já autoriza a presunção de irregularidade. Dessa forma, o ônus da prova da aplicação dos recursos recai sobre o gestor, cabendo-lhe comprovar a boa utilização dos mesmos, que não pode ser, senão, para o atendimento do interesse público.

A jurisprudência do Tribunal de Contas da União consolidou tal entendimento no Enunciado da Decisão 176 (BRASIL, 2005), onde estabelece que, compete ao gestor comprovar a boa e regular aplicação dos recursos públicos, cabendo-lhe o ônus da prova.

A portaria $\mathrm{n}^{\circ} 127$ determina a prestação de contas da seguinte maneira:

Art. 56. O órgão ou entidade que receber recursos na forma estabelecida nesta Portaria estará sujeito a prestar contas da sua boa e regular aplicação no prazo máximo de trinta dias contados do término da vigência do convênio ou contrato ou do último pagamento efetuado, quando este ocorrer em data anterior àquela do encerramento da vigência.

$\S 1^{\circ}$ Quando a prestação de contas não for encaminhada no prazo estabelecido no caput, o concedente ou contratante estabelecerá o prazo máximo de trinta dias para sua apresentação, ou recolhimento dos recursos, incluídos os rendimentos da aplicação no mercado financeiro, atualizados monetariamente e acrescido de juros de mora, na forma da lei.

$\S 2^{\circ} \mathrm{Se}$, ao término do prazo estabelecido, o convenente ou contratado não apresentar a prestação de contas nem devolver os recursos nos termos do $\S 1^{\circ}$, o concedente registrará a inadimplência no SICONV por omissão do dever de prestar contas e comunicará o fato ao órgão de contabilidade analítica a que estiver vinculado, para fins de instauração de tomada de contas especial sob aquele argumento e adoção de outras medidas para reparação do dano ao erário, sob pena de responsabilização solidária. (BRASIL, 2008a).

O texto da referida portaria determina que, o prazo para a prestação de contas do recurso recebido é de trinta dias, contados do termino da vigência do convênio.

O texto também referencia que, caso a prestação não seja encaminhada no período estabelecido, o concedente ou contratante, estabelecerá igual prazo para a apresentação das contas ou o recolhimento do recurso, atualizado monetariamente, com juros e mora. Se ainda assim, a prestação não for apresentada e os recursos não forem devolvidos pelo convenente ou 
contratado, será registrada a inadimplência no SICONV e o órgão fiscalizador será comunicado para a instauração da tomada de contas especial.

Insere-se ainda do texto, que o gestor terá a responsabilidade solidária pela não prestação de contas, caso não comunique o fato ao órgão de contabilidade analítica, que é o órgão ao qual o convenente está vinculado, isto é, o órgão concedente da transferência voluntária.

Sobre a documentação necessária a prestação de contas, além dos documentos apresentados no SICONV, a portaria $\mathrm{n}^{\circ} 127$ determina:
Art. $58[\ldots]$
I - Relatório de Cumprimento do Objeto;
II - declaração de realização dos objetivos a que se propunha o instrumento;
III - relação de bens adquiridos, produzidos ou construídos, quando for o caso;
IV - a relação de treinados ou capacitados, quando for o caso;
$\mathrm{V}$ - a relação dos serviços prestados, quando for o caso;
VI - comprovante de recolhimento do saldo de recursos, quando houver; e
VII - termo de compromisso por meio do qual o convenente ou contratado será obrigado a manter os documentos relacionados ao convênio ou contrato de repasse, nos termos do $\S 3^{\circ}$ do art. $3^{\circ}$. (BRASIL, 2008a).

Após a entrega da documentação necessária para a prestação de contas, o concedente terá um prazo de noventa dias para a análise das contas, conforme estabelecido:

\begin{abstract}
Art. 60. A autoridade competente do concedente ou contratante terá o prazo de noventa dias, contado da data do recebimento, para analisar a prestação de contas do instrumento, com fundamento nos pareceres técnico e financeiro expedidos pelas áreas competentes.

$\S 1^{\circ} \mathrm{O}$ ato de aprovação da prestação de contas deverá ser registrado no SICONV, cabendo ao concedente ou contratante prestar declaração expressa de que os recursos transferidos tiveram boa e regular aplicação.

$\S 2^{\circ}$ Caso a prestação de contas não seja aprovada, exauridas todas as providências cabíveis para regularização da pendência ou reparação do dano, a autoridade competente, sob pena de responsabilização solidária, registrará o fato no SICONV e adotará as providências necessárias à instauração da Tomada de Contas Especial, com posterior encaminhamento do processo à unidade setorial de contabilidade a que estiver jurisdicionado para os devidos registros de sua competência. (BRASIL, 2008a).
\end{abstract}

Pelo texto legal, podemos concluir que tanto a aprovação, quanto a não aprovação devem ser registradas no SICONV e caso não seja aprovada, devem ser tomadas as providencias cabíveis para a instauração da tomada de contas especial, sob pena de responsabilidade solidária do gestor concedente.

\title{
2.3 - O controle na Administração Pública
}

“A administração deve dispor de estrutura que se submeta aos princípios constitucionais da legalidade, impessoalidade, moralidade, publicidade e eficiência, princípios 
estes basilares no Estado Democrático de Direito, servindo assim como parâmetro à atividade de controle". (ZYMLER, 2001).

Portanto, a administração pública deve cumprir os princípios, garantidos pela constituição, para que o controle possa ser exercido tanto pela sociedade, como pelos órgãos controladores do governo.

"O controle dos gastos é fundamental para a eficiência do Estado, para a oferta de bens e serviços em níveis adequados à sociedade e para a regularidade no desembolso dos recursos ofertados pelos contribuintes. Tal como nas finanças pessoais ou no setor privado, a conduta leviana dos gastos públicos pode resultar na falência do país”. (VIEIRA JUNIOR, 2006).

Principalmente, ao se tratar de dinheiro público, que conforme o próprio nome diz, é público, isto é, de todos os contribuintes, o controle há de ser ainda mais eficaz e deve garantir a eficiência da gestão da coisa pública, como também da legalidade da conduta do agente público.

Para Meireles (2003, p.636), “controlar um órgão ou autoridade administrativa é impor limites aos governantes, é orientar a melhor utilização dos recursos disponíveis de forma organizada e ponderada".

Portanto, limites devem ser impostos para balizar os atos dos agentes e garantir a correta utilização dos recursos públicos.

Com o advento da Lei Complementar $\mathrm{n}^{\circ}$ 101, denominada Lei de Responsabilidade Fiscal - LRF, (BRASIL, 2000b) mecanismos importantes de controle e acompanhamento dos gastos foram instituídos. De forma complementar, tal legislação definiu importantes condutas não abordadas de forma tão específica na Constituição Federal (BRASIL, 1988), na Lei no 4.320 (BRASIL, 1964) e na Lei ${ }^{\circ} 8.666$ (BRASIL, 1993).

Sobre essa legislação Vieira Junior (2006) ainda lembra que "novos enfoques foram dados em relação às despesas governamentais, visando principalmente o controle do aumento dos gastos governamentais e a responsabilização dos agentes públicos na assunção de compromissos que possam resultar em desembolso de recursos públicos”.

Dessa forma, a Lei de responsabilidade fiscal (BRASIL, 2000b), tenta direcionar os atos dos agentes públicos e definir sanções para a má gestão dos recursos públicos, definindo responsabilidades para os gestores e estabelecer formas de controle dos gastos governamentais.

Di Pietro (2005, p.637) afirma que o controle da atividade administrativa pode ser definido como "o controle de fiscalização e correção que sobre ela (a administração) exercem os órgãos dos Poderes Judiciário, Legislativo e Executivo, com o objetivo de garantir a 
conformidade de sua atuação com os princípios que lhe são impostos pelo ordenamento jurídico".

Portanto, conforme o autor, conclui-se que o controle dos atos da Administração Pública deve ser exercido pelos três poderes, o legislativo, o executivo e o judiciário com o objetivo de se fazer cumprir os princípios constitucionais.

O controle é instrumento eficaz de gestão e não é novidade do ordenamento jurídico brasileiro. A Constituição Federal define que, para as diversas formas de execução da fiscalização pública, dois tipos de controle devem ser realizados, o controle externo e o controle interno:

Art. 70 A fiscalização contábil, financeira, orçamentária, operacional e patrimonial da União e das entidades da administração direta, indireta, quanto à legalidade, legitimidade, economicidade, aplicação de subvenções e renúncia de receitas, será exercida pelo Congresso Nacional, mediante controle externo, e pelo sistema de controle interno de cada poder.

Art. 71: O controle externo, a cargo do Congresso Nacional, será exercido com o auxílio do Tribunal de Contas da União.

Art. 74. Os Poderes Legislativo, Executivo e Judiciário manterão, de forma integrada, sistema de controle interno com a finalidade de:

I - avaliar o cumprimento das metas previstas no plano plurianual, a

Execução dos programas de governo e dos orçamentos da União;

II - comprovar a legalidade e avaliar os resultados, quanto à eficácia e eficiência, da gestão orçamentária, financeira e patrimonial nos órgãos e entidades da administração federal, bem como da aplicação de recursos públicos por entidades de direito privado;

III - exercer o controle das operações de crédito, avais e garantias, bem como dos direitos e haveres da União;

IV - apoiar o controle externo no exercício de sua missão institucional.

$\S 1$.o - Os responsáveis pelo controle interno, ao tomarem conhecimento de qualquer irregularidade ou ilegalidade, dela darão ciência ao Tribunal de Contas da União, sob pena de responsabilidade solidária.

§ 2.0 - Qualquer cidadão, partido político, associação ou sindicato é parte legítima para, na forma da lei, denunciar irregularidades ou ilegalidades perante o Tribunal de Contas da União. (BRASIL, 1988).

Pelo texto constitucional, entende-se que o controle interno atua de forma a verificar os atos administrativos em sentido abrangente e os agentes responsáveis pelo controle interno deverão informar ao Tribunal de Contas da União, responsável pelo controle externo, como também para os tribunais de contas dos Estados e Municípios, qualquer irregularidade ou ilegalidade encontrada na execução da gestão administrativa.

O texto inclusive impõe sanções aos agentes responsáveis pelo controle interno, quanto ao não repasse das irregularidades encontradas, acarretando responsabilidade solidaria com o mau gestor da coisa pública. Portanto, a conduta do agente deve ser pautada nas praticas dos princípios administrativos e o controle vai apurar a conformidade de seus atos.

Destaca-se então, o papel fundamental do controle interno de se antever ao controle externo na atividade de fiscalização e controle, dando subsídios para a atuação dos tribunais 
de contas. Pode-se interpretar, portanto, que o controle interno atua em cooperação com o controle externo e é por meio da operacionalização do controle interno, controle prévio, que o controle externo terá subsídios para a sua boa atuação, no controle posterior.

\title{
2.3.1 - O Controle Interno
}

O controle pode ser feito pela sociedade em geral, pela própria Administração, pelo Poder Legislativo, pelo Ministério Público e pelos Tribunais de Contas. Moreira (2005) explica que:

\begin{abstract}
Quando o agente controlador integra a própria Administração, se está diante de um controle interno, exercido por ela mesma sobre seus órgãos e suas entidades da Administração Indireta. Se o controle é efetuado por órgão, ente ou instituição exterior à estrutura da Administração, qualifica-se como controle externo, situandose nesta espécie o controle realizado por instituições políticas (Poder Legislativo), por instituições técnicas (Tribunais de Contas) e por instituições precipuamente jurídicas (Judiciário).
\end{abstract}

Portanto, o controle interno é aquele efetuado dentro da própria estrutura do órgão, mas pode ser controlado externamente por instituições políticas, técnicas e jurídicas.

Almeida (1996, p.50), define também que "o controle interno é um conjunto de métodos e procedimentos adotados pelas organizações, com objetivos de proteger os ativos, produzir dados contábeis confiáveis, ajudar a administração na condução ordenada de seus negócios, bem como promover a eficiência operacional".

Assim, toda a atividade da Administração Pública, deve ser controlada, ou seja, o controle interno deve ser capaz de proteger os recursos públicos, de prover dados íntegros e confiáveis de forma a promover a boa gestão pública e um bom desempenho operacional.

Sobre os controles administrativos Fêu (2003) lembra que:

São denominados genericamente de controles internos. Fazem parte da estrutura administrativa de cada poder, tendo por função acompanhar a execução dos seus atos, indicando, em caráter opinativo, preventivo ou corretivo, ações a serem desempenhadas com vistas ao atendimento da legislação.

Dessa forma, o controle interno deve agir de forma opinativa, dando suporte a execução dos atos administrativos; de forma preventiva, prevenindo possíveis irregularidades e também de forma corretiva, quando da ocorrência de ilegalidades na prática do ato de forma a cumprir os princípios impostos pela legislação e garantir a aplicação dos recursos em benefício do bem comum.

O Sistema de Controle Interno do Poder Executivo Federal é disciplinado pelo decreto $\mathrm{n}^{\mathrm{o}} 3.591$ que define:

Art.1 O Sistema de Controle Interno do Poder Executivo Federal visa à avaliação da ação governamental e da gestão dos administradores públicos federais. 
$[\ldots]$

Art.8 A Controladoria-Geral da União, como Órgão Central, incumbido da orientação normativa e da supervisão técnica dos órgãos que compõem o Sistema, integra o Sistema de Controle Interno do Poder Executivo Federal e que a Secretaria Federal de Controle Interno desempenhará as funções operacionais de competência do Órgão Central do Sistema, na forma definida no regimento interno, além das atividades de controle interno de todos os órgãos e entidades do Poder Executivo Federal, excetuados aqueles jurisdicionados aos órgãos setoriais, quais sejam, as Secretarias de Controle Interno (CISET) da Casa Civil, da Advocacia-Geral da União, do Ministério das Relações Exteriores e do Ministério da Defesa, como órgãos setoriais. (BRASIL, 2000a).

Pelo texto, tem-se que a Controladoria Geral da União (CGU) é o órgão central do Poder Executivo Federal responsável, entre outras funções, pelo acompanhamento, orientação, supervisão e avaliação das ações do governo e integra o Sistema de Controle Interno do Poder Executivo Federal.

A função operacional é exercida pela Secretaria Federal de Controle Interno onde:

Essa atribuição é exercida pela CGU por meio da sua Secretaria Federal de Controle Interno, área responsável por avaliar a execução dos orçamentos da União, fiscalizar a implementação dos programas de governo e fazer auditorias sobre a gestão dos recursos públicos federais sob a responsabilidade de órgãos e entidades públicos e privados, entre outras funções. (BRASIL, 2000a).

Portanto, cabe à Secretaria Federal de Controle Interno as funções de avaliação, fiscalização e auditoria sobre a gestão dos recursos públicos na execução do orçamento e implementação de programas de governo, aplicados pelos órgãos e entidades públicas e privadas.

\subsection{2 - O Controle Externo}

O controle externo exercido pelo Congresso Nacional sobre a administração financeira e orçamentária assenta suas bases no arts. 70 e 71 da Constituição Federal:

Art. 70 A fiscalização contábil, financeira, orçamentária, operacional e patrimonial da União e das entidades da administração direta, indireta, quanto à legalidade, legitimidade, economicidade, aplicação de subvenções e renúncia de receitas, será exercida pelo Congresso Nacional, mediante controle externo, e pelo sistema de controle interno de cada poder.

Parágrafo único. Prestará contas qualquer pessoa física ou jurídica, pública ou privada, que utilize, arrecade, guarde, gerencie, ou administre dinheiros, bens e valores públicos ou pelos quais a União responda, ou que, em nome desta, assuma obrigações de natureza pecuniária.

Art. 71: O controle externo, a cargo do Congresso Nacional, será exercido com o auxílio do Tribunal de Contas da União. (BRASIL, 1988).

Pelo texto constitucional, a fiscalização dos atos administrativos praticados pelas entidades da administração direta e indireta se baliza no cumprimento dos princípios constitucionais e é exercida tanto pelo controle externo, pelo Congresso Nacional com o auxílio do Tribunal de Contas da União, como pelo controle interno de cada poder. 
Pelo texto, conclui-se também que quando da utilização, arrecadação, guarda e administração de recursos públicos há de se haver a prestação de contas por qualquer pessoa física, jurídica, entidade pública ou privada que assumiu obrigações de natureza pecuniária em nome da União.

Ainda sobre o controle externo Zymler (2001) lembra que:

É o controle exercido por órgãos alheios ao Poder Executivo. O controle externo pode ser exercido pelo Poder Judiciário e pelo Poder Legislativo. O controle externo exercido pelo Poder Legislativo desdobra-se em duas vertentes: o controle político, realizado pelas Casas Legislativas, e o controle técnico, que abrange a fiscalização contábil, financeira e orçamentária, exercido com auxílio do Tribunal de Contas da União.

Afirma o autor, que o controle externo pode ser exercido pelo poder judiciário e legislativo e que há um controle político e um controle técnico, o qual contempla a fiscalização da aplicação contábil, financeira e orçamentária dos recursos da União e é exercido com o auxílio do Tribunal de contas da União.

A Constituição Federal conferiu ao TCU o papel de auxiliar o Congresso Nacional no exercício do controle externo. Portanto cabe a esse tribunal:

No auxílio ao Congresso Nacional, exercer a fiscalização contábil, financeira, orçamentária, operacional e patrimonial da União e das entidades da administração direta e indireta, quanto à legalidade, à legitimidade e à economicidade e a fiscalização da aplicação das subvenções e da renúncia de receitas. Qualquer pessoa física ou jurídica, pública ou privada, que utilize, arrecade, guarde, gerencie ou administre dinheiros, bens e valores públicos ou pelos quais a União responda, ou que, em nome desta, assuma obrigações de natureza pecuniária tem o dever de prestar contas ao TCU. (BRASIL, 1988).

Assim, de forma a garantir o cumprimento dos princípios constitucionais e zelar pelos recursos públicos, foi dado ao TCU o dever de fiscalizar a aplicação do dinheiro público, nos aspectos contábil, financeiro, orçamentário e patrimonial. Dessa forma qualquer pessoa física, jurídica ou entidade pública ou privada tem o deve de prestar contas a esse tribunal.

Além de promover a fiscalização da aplicação dos recursos públicos, as demais competências constitucionais do TCU assim se resumem, conforme o seu regimento interno:

Art. $1[\ldots]$

- fiscalizar as aplicações de subvenções e a renúncia de receitas.

- realizar inspeções e auditorias por iniciativa própria ou por solicitação do Congresso Nacional;

- fiscalizar as contas nacionais das empresas supranacionais;

- fiscalizar a aplicação de recursos da União repassados a Estados, ao Distrito Federal ou a Municípios;

- prestar informações ao Congresso Nacional sobre fiscalizações realizadas;

- aplicar sanções e determinar as providências necessárias ao exato cumprimento da lei, se verificada ilegalidade;

- apurar denúncias apresentadas por qualquer cidadão, partido político, associação ou sindicato sobre irregularidades ou ilegalidades;

- fixar os coeficientes dos fundos de participação dos Estados, do Distrito Federal e dos Municípios e fiscalizar a entrega dos recursos aos governos estaduais e às prefeituras. (BRASIL, 2002). 
De acordo com o regimento, além da função fiscalizadora, o Tribunal de contas da União também tem a responsabilidade de prestar informações ao Congresso Nacional acerca das fiscalizações realizadas, apurar denúncias e aplicar sanções para a reparação do dano, realizar inspeções e auditorias e ainda fixar os coeficientes dos fundos de participação dos Estados, Distrito Federal e Municípios.

Além das atribuições previstas na Constituição e no regimento interno, várias outras têm sido conferidas ao TCU por meio de leis específicas. "Destacam-se entre elas, as atribuições conferidas ao Tribunal pela Lei de Responsabilidade Fiscal, pela Lei de Licitações e Contratos e, anualmente, pela Lei de Diretrizes Orçamentárias”. (BRASIL, 2008b).

Zymler (2001) destaca ainda outras competências do Tribunal, quais sejam:

As competências constitucionais do TCU dividem-se em parajudiciais e
fiscalizadoras. A função parajudicial é desempenhada quando o Tribunal julga as
contas dos administradores e demais responsáveis por dinheiros, bens e valores
públicos, nos processos de tomada e prestação de contas anual ou tomada de contas
especial, bem assim quando aprecia a legalidade dos atos de admissão de pessoal e
de concessão de aposentadorias, reformas e pensões civis e militares, para fins de
registro.

Portanto, além de fiscalizar os atos de governo, é de competência do TCU o julgamento das contas apresentadas pelos agentes públicos e demais responsáveis por dinheiros, bens e valores públicos. Em conseqüência, aplica-se os processos de tomada e prestação de contas.

Dentre as competências institucionais do TCU, inclui-se a aplicação de penalidades aos responsáveis por ilegalidades ou irregularidades nos atos de gestão. Sendo assim, compete também ao tribunal, segundo afirma Zymler (2001):

As sanções previstas nas normas constitucionais, legais e regimentais incluem
aplicação de multa e devolução do débito apurado, afastamento provisório do cargo,
solicitação do arresto e declaração de indisponibilidade dos bens de responsáveis
julgados em débito, declaração de inidoneidade de licitantes e inabilitação para o
exercício de cargo em comissão ou função de confiança no âmbito da administração
pública federal.

Sendo assim, constatada a irregularidade, o próprio Tribunal tem a prerrogativa de aplicar as sanções necessárias à reparação do dano ao erário e punição dos responsáveis.

\section{4 - Tomada de contas especial}

"A Tomada de Contas Especial é um processo devidamente formalizado, dotado de rito próprio, que objetiva apurar os fatos, identificar os responsáveis e quantificar o dano causado ao Erário, visando ao seu imediato ressarcimento”. (BRASIL, 2008b). 
Sobre a tomada de contas especial o regimento interno do TCU estabelece:

Art. 197. Diante da omissão no dever de prestar contas, da não-comprovação da aplicação dos recursos repassados pela União na forma prevista no inciso VIII do art. $5^{\circ}$, da ocorrência de desfalque ou desvio de dinheiros, bens ou valores públicos, ou, ainda, da prática de qualquer ato ilegal, ilegítimo ou antieconômico de que resulte dano ao erário, a autoridade administrativa competente, sob pena de responsabilidade solidária, deverá imediatamente adotar providências com vistas à instauração de tomada de contas especial para apuração dos fatos, identificação dos responsáveis e quantificação do dano.

$\S 1^{\circ}$ Não providenciado o disposto no caput, o Tribunal determinará a instauração de tomada de contas especial, fixando prazo para cumprimento dessa decisão.

$\S 2^{\circ}$ Esgotadas todas as medidas ao alcance da autoridade administrativa e do órgão do controle interno, visando à apuração dos fatos irregulares, à perfeita identificação dos responsáveis e ao ressarcimento do erário, a tomada de contas especial será encaminhada ao Tribunal para julgamento, observado, quando couber, o art. 206.

$\S 3^{\circ} \mathrm{Na}$ ocorrência de perda, extravio ou outra irregularidade sem que se caracterize a má-fé de quem lhe deu causa, se o dano for imediatamente ressarcido, a autoridade administrativa competente deverá, em sua tomada ou prestação de contas ordinária, comunicar o fato ao Tribunal, ficando dispensada desde logo a instauração de tomada de contas especial. (BRASIL, 2002).

Entende-se pelo regimento, que o processo de tomada de contas especial somente é instaurado, nos casos de comprovada irregularidade na prestação de contas ordinária. A aplicação dos recursos públicos é avaliada pelo órgão de controle interno e ocorrendo alguma evidência de ilegalidade deve ser instaurado o processo de tomada de contas especial no Tribunal de contas da União, com vistas a apurar os fatos irregulares, responsabilizar os agentes e efetuar o ressarcimento ao erário do dano causado. Entretanto, o processo somente é instaurado, quando exauridas todas as medidas para o atingimento da regularidade. Caso o dano seja imediatamente reparado, a autoridade competente comunica o fato ao Tribunal e a tomada de contas especial é dispensada.

Duas fases, interna e externa, dividem o processo de tomada de contas especial. Sobre a fase interna Bastos Neto (2008, p.131) lembra:

É um procedimento de caráter excepcional - somente se instaura TCE se, no prazo de 180 dias da ocorrência do fato, forem infrutíferos os esforços pela recomposição do erário,

Não há partes - não há lide ou litígio subjacente nessa fase, até porque, se houvesse, caberia a própria administração, que apurou o fato, julgar o processo;

A administração, por intermédio da TCE, não julga; e

Possuindo natureza nitidamente verificadora e investigatória, deve declarar o valor correspondente ao dano e os indícios da autoria - todas as conclusões do trabalho devem corresponder à devida fundamentação e a correlação entre o indicio e o fato apurado, formando um conjunto harmônico para sustentar a acusação perante os tribunais de contas e, eventualmente, resistir ao crivo do Poder Judiciário.

Como se vê, na fase interna ainda não se tem um processo instaurado, não há lide e, portanto, não se tem ainda as partes. $O$ que se quer nesta fase é a simples comprovação da ocorrência ou não da irregularidade com a devida fundamentação dos fatos apurados.

A ausência de adoção das providências mencionadas, no prazo de 180 (cento e oitenta) dias, contado, nos casos de omissão no dever de prestar contas e da não 
comprovação da aplicação dos recursos repassados, da data fixada para apresentação da prestação de contas; e, nos demais casos, da data do fato gerador, quando conhecida, ou da data de ciência do fato pela administração; caracteriza grave infração à norma legal, e sujeita a autoridade administrativa federal omissa à responsabilidade solidária e às sanções cabíveis. (BRASIL, 2007a).

Assim, a responsabilidade pela ausência de adoção de providências para a efetiva comprovação da boa aplicabilidade dos recursos públicos, recai sobre a autoridade administrativa federal competente pela análise e fiscalização das contas.

Caso haja indícios comprobatórios da irregularidade, o processo é encaminhado ao Tribunal de Contas da União, onde se inicia a fase externa, que terá por finalidade firmar a responsabilidade dos agentes envolvidos. Sobre essa fase, Bastos Neto (2008, p.132) afirma:

Deve ser apurada a responsabilidade por omissão ou irregularidade no dever de
prestar contas ou por dano causado ao erário; e certificar a regularidade ou
irregularidade das contas e identificar, no âmbito da administração pública, latu
sensu, o agente público responsável por: omissão no dever de prestar contas;
prestação de contas de forma irregular; e dano ao erário.

Conclui-se pela afirmação que essa é a fase processual da tomada de contas especial, onde haverá o julgamento da irregularidade ou regularidade das contas, com manifestação da parte interessada e imputação da responsabilidade do débito. 


\section{Metodologia}

\section{1 - Tipo de pesquisa}

O estudo vai envolver pesquisa bibliográfica e documental na identificação dos principais aspectos que motivaram o governo federal a implantar um Sistema de Gestão de Convênios, na descrição das mudanças significativas na legislação e as principais alterações nas fases de celebração, execução e prestação de contas, como também na descrição do Portal de Convênios e identificação dos principais aspectos da nova forma de operacionalização das transferências voluntárias e como essa nova abordagem poderá auxiliar o Tribunal de Contas da União, no processo de tomada de contas especial.

O propósito da pesquisa bibliográfica é descrever os conceitos relativos às transferências de recursos da União mediante convênios, explicitar as diferentes fases do convênio, como se dá o processo de tomada de contas especial e de que forma é realizado o controle e fiscalização dessa forma de transferência e a competência dos órgãos de controle da Administração Pública. A pesquisa bibliográfica será obtida a partir de livros, artigos científicos, publicações, revistas especializadas e legislação, retiradas principalmente da internet, nos sites de publicações cientificas e oficiais do Governo Federal.

A pesquisa será também documental porque se valerá de documentos internos da instituição que digam respeito ao objeto de estudo, como, por exemplo: regimento interno, lei orgânica e também de documentos com descrição de aspectos funcionais e operacionais do sistema de informática objeto do estudo.

\section{2 - Caracterização da organização}

A organização juntamente com o Congresso Nacional tem a função fiscalizadora dos gastos do Governo Federal, onde atua como órgão de controle externo. Faz a análise da gestão de recursos, fiscaliza os entes Federados e analisa a prestação de contas do Governo Federal, entre outras.

Com a Constituição de 1988, o Tribunal de Contas da União teve a sua jurisdição e competência substancialmente ampliadas. Recebeu poderes para, no auxílio ao Congresso Nacional, exercer a fiscalização contábil, financeira, orçamentária, operacional e patrimonial da União e das entidades da administração direta e indireta, quanto à legalidade, à legitimidade, à economicidade e a fiscalização da aplicação das subvenções e da renúncia de 
receitas. Qualquer pessoa física ou jurídica, pública ou privada, que utilize, arrecade, guarde, gerencie ou administre dinheiros, bens e valores públicos ou pelos quais a União responda, ou que, em nome desta, assuma obrigações de natureza pecuniária tem o dever de prestar contas ao TCU.

\section{3 - Participantes da Pesquisa e amostra de documentos}

A pesquisa será baseada principalmente no controle da transferência voluntária de recursos mediante convênios. Serão analisados documentos comprobatórios que motivaram o surgimento de discussões entre as autoridades competentes sobre a forma de controle e fiscalização dos recursos públicos.

Serão também analisados documentos de especificação de sistemas, contendo características funcionais e operacionais, estudos e documentos que comprovam as fraudes e irregularidades encontradas na aplicação do recurso público.

\subsubsection{Critério de Seleção de participantes ou da amostra}

O critério de seleção para o estudo dos convênios se baseia no fato de que essa forma de transferência vem sofrendo um aumento de volume nos últimos anos, o que mostra a necessidade de um maior acompanhamento e controle dos órgãos competentes e também da descoberta de inúmeros casos de corrupção que vem ocorrendo na aplicação de recursos públicos provenientes dessa forma de transferência.

\section{4 - Instrumento}

O instrumento da pesquisa será baseado em legislações, artigos científicos, publicações, livros e também de documentos internos da instituição em estudo, documentos de especificação de sistemas, alem de publicações e depoimentos encontrados em jornais e revistas.

\section{5 - Procedimentos de coleta dos dados}

A pesquisa documental e bibliográfica será feita por meio de documentação obtida junto à internet em arquivos científicos, portais oficiais, legislação, regimentos, entre outros. 


\section{6 - Análise dos dados}

Será feita uma análise do conteúdo obtido na pesquisa documental, na identificação dos fatores motivadores da implantação de um sistema para gerir os convênios, na descrição das principais alterações na legislação dessa forma de transferência, como também na apresentação do Portal de convênios e suas características funcionais e operacionais de forma que seja possível avaliar a viabilidade desse portal no auxilio ao processo de tomada de contas especial realizado pelo TCU.

\section{Discussões e Resultados}

\subsection{Principais fatores que motivaram a criação do Sistema de Gestão de Convênios}

O desbaratamento de um esquema criminoso, com inicio em 2002, envolvendo manipulação de licitações a fim de desviar recursos do orçamento federal, iniciou a instauração de procedimentos específicos de ação fiscal nas empresas supostamente integrantes do "esquema".

De acordo com o relatório final da CPMI das ambulâncias (BRASIL, 2006a), que partiu da instauração de uma comissão para apuração de denuncias relativas a fraudes na aplicação de dinheiro público verificou-se que:

\footnotetext{
Diante da constatação de que se tratava de uma organização criminosa complexa e direcionada à apropriação em larga e profusa escala de recursos do Orçamento Geral da União, deu-se inicio aos trabalhos de inteligência pela Polícia Federal, onde verificou-se que a organização criminosa derivava da associação de políticos, empresários e servidores públicos para a promoção ampla e diversificada de fraudes a licitações e abatimento de verbas públicas em âmbito nacional.

O "esquema" criminoso agiu de forma linear durante vários anos objetivando a apropriação de recursos públicos em larga e profusa escala. Para a execução dos delitos, os integrantes da mencionada organização criminosa monitoravam permanentemente a formalização e a aprovação do Orçamento Geral da União, notadamente as emendas apresentadas individualmente por parlamentares. Na etapa seguinte, agiam no sentido de controlar a sua execução orçamentária, interferindo na liquidação de despesas e na prestação de contas dos convênios então formalizados entre a União Federal, municípios e organizações sociais de interesse público, bem como cuidavam da elaboração de projetos sem os quais não era possível a descentralização dos recursos públicos. (BRASIL, 2006a).
}

Dessa forma, o "esquema" atuou na origem da verba federal, logo após a votação do orçamento da União, monitorou a liberação dos recursos, interferiu ilicitamente em todas as fases da licitação e na execução e controle do objeto licitado.

O relatório ainda aponta que, 


\begin{abstract}
Atuou, pois em toda a seqüência de atos administrativos, de sua fase antecedente e preparatória, qual seja, de apresentação de emendas junto à Comissão Mista de Orçamento do Congresso Nacional, à aprovação dos planos de trabalho e projetos técnicos perante o Fundo Nacional de Saúde, na assinatura dos convênios, na liberação dos recursos, na adjudicação do processo de licitação, na liquidação das despesas e na prestação de contas. (BRASIL, 2006a).
\end{abstract}

Isto é, nenhuma etapa de tramitação do processo, político ou burocrático fugiu ao controle da organização criminosa, de modo que foi estabelecido um domínio permanente sobre todo o fluxo de recursos federais destinado à execução de parcela substancial da política pública.

Com isso, é notório o problema da deficiência da estrutura de controle por parte dos órgãos descentralizadores de recursos, bem como nos estados e municípios.

Partindo desse pressuposto, Lambranho e Militão (2008) revelam que "dos R \$ 3,3 bilhões em convênios inadimplentes, apenas R $\$ 267$ milhões (8\%) são objeto de tomada de contas especial, instrumento adotado pela administração pública após o esgotamento de todas as medidas administrativas para tentar reparar os prejuízos causados aos cofres públicos".

Segue tabela representativa sobre os dados referentes aos convênios que apresentaram problemas, desde a implantação do SIAFI em 1987 a dezembro de 2008.

Tabela 1: Convênios com problemas

\begin{tabular}{|c|c|c|c|}
\hline Problema & Total & $\begin{array}{c}\text { Sem tomada de } \\
\text { contas }\end{array}$ & $\%$ \\
\hline Inadimplentes & $1.115 .086 .423,71$ & $937.431 .605,94$ & $84,1 \%$ \\
\hline $\begin{array}{l}\text { Inadimplência } \\
\text { suspensa }\end{array}$ & $2.209 .839 .282,49$ & $2.120 .286 .785,11$ & $95,9 \%$ \\
\hline $\begin{array}{l}\text { Sem prestação de } \\
\text { contas* }\end{array}$ & $50.716 .406 .324,46$ & $50.716 .406 .324,46$ & $100 \%$ \\
\hline $\begin{array}{l}\text { Sem prestação } \\
\text { analisada* }\end{array}$ & $16.617 .190 .323,60$ & $16.587 .230 .508,42$ & $99,8 \%$ \\
\hline TOTAL & $70.658 .522 .354,26$ & $70.361 .355 .223,93$ & $99,6 \%$ \\
\hline
\end{tabular}

Os dados se referem aos repasses federais feitos desde que o Siafi foi criado, em 1987, até o dia 08 de dezembro de 2008, e demonstram que o governo acumula um passivo de convênios sem fiscalização a cada ano.

Sobre os convênios sem a devida prestação de contas, segue a análise na tabela abaixo: 
Tabela 2: Convênios sem prestação de contas

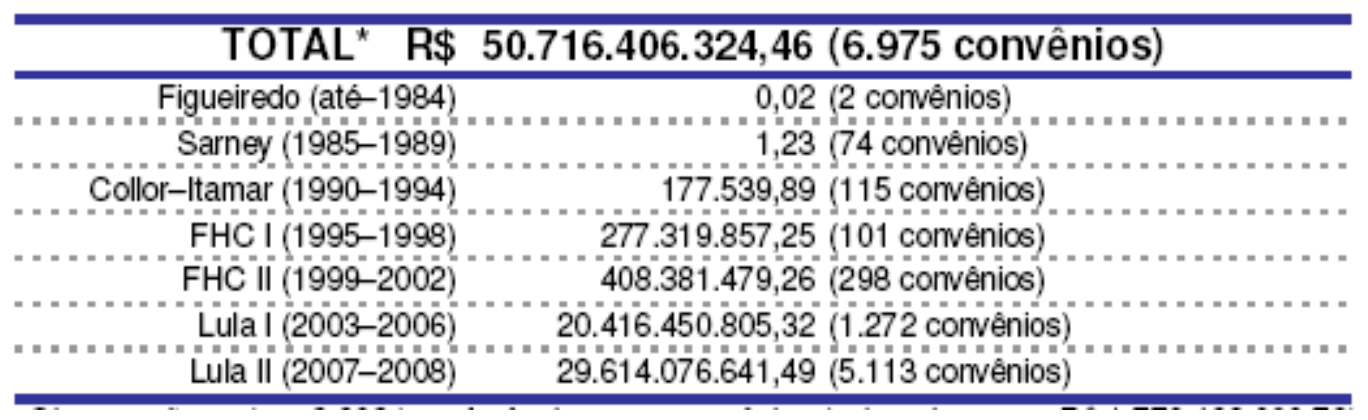

Fonte: SIAFI

*Dados coletados de 1987 a 2008

* outras 3.892 transferências para convênios (cujo valor soma $R \$ 1.773 .432 .009,76$ ) estão dentro do prazo de 60 dias para a entrega da prestação de contas, conforme a IN-STN 1/97.

O levantamento mostra que a maior parte dos recursos não fiscalizados pela União refere-se às transferências de recursos a entidades que simplesmente não prestaram contas (R \$ 50,7 bilhões). Não necessariamente esses recursos foram mal empregados pelos tomadores do dinheiro. Mas o fato de não haver a prestação de contas ou de ela ainda não ter sido analisada abre brechas para irregularidades que não são descobertas.

Cabe ressaltar o fato de que, houve um aumento de volume muito expressivo de convênios no período de 2002 a 2008. Entretanto, não há necessidade de investigação, pois nem sequer houve a fase preliminar de recebimento e avaliação da prestação de contas.

Destaca-se, portanto, o crescimento do número de convênios sem a prestação de contas no período de 2002 a 2008, até porque o aumento no montante de transferências apresentou um acréscimo de mais de $80 \%$ neste período, conforme dados da STN.

Tabela 3: Transferências a Estados e Municípios

\begin{tabular}{|c|c|c|c|c|c|c|c|c|}
\hline \multicolumn{9}{|c|}{ Transferências Voluntárias a Estados e Municípios no período de 2002 a 2008* (mil R\$) } \\
\hline $\begin{array}{c}\text { ÓRGÃOS } \\
\text { BENEFICIADOS }\end{array}$ & $\begin{array}{c}2002 \\
\text { ACUMULADO }\end{array}$ & $\begin{array}{c}2003 \\
\text { ACUMULADO }\end{array}$ & $\begin{array}{c}2004 \\
\text { ACUMULADO }\end{array}$ & $\begin{array}{c}2005 \\
\text { ACUMULADO }\end{array}$ & $\begin{array}{c}2006 \\
\text { ACUMULADO }\end{array}$ & $\begin{array}{c}2007 \\
\text { ACUMULADO }\end{array}$ & $\begin{array}{c}2008 \\
\text { ACUMULADO }\end{array}$ & TOTAL \\
\hline ESTADOS & 2.476 .070 & 2.406 .374 & 2.734 .430 & 3.050 .378 & 3.230 .344 & 4.130 .346 & 2.551 .879 & 20.579 .821 \\
\hline MUNICÍPIOS & 2.193.591 & 2.597 .837 & 3.009 .517 & 3.517 .667 & 4.076 .758 & 4.377 .373 & 4.052 .818 & 23.825.561 \\
\hline TOTAL: & 4.669 .66 & 5.004.211 & 5.743 .947 & 6.568 .045 & 7.307.102 & 8.507.719 & 6.604.697 & 44.405 .382 \\
\hline
\end{tabular}

Fonte: STN/MF (2008)

* Dados de janeiro a outubro de 2008

De acordo com os dados apresentados na tabela, no período compreendido entre 2002 e outubro de 2008 foram transferidos $\mathrm{R} \$$ 44.405.382,00 (quarenta e quatro bilhões, quatrocentos e cinco milhões e trezentos e oitenta e dois mil reais) a Estados, Municípios e Instituições Privadas sem fins lucrativos. 
Verifica-se, por fim, que o total de recursos transferidos voluntariamente passou de 4,66 bilhões em 2002 para 8,5 bilhões em 2007.

Em três anos, os recursos transferidos sofreram um acréscimo de mais de $80 \%$, ocasionando por conseqüência, um aumento do numero de transferências sem a devida comprovação da boa e regular aplicabilidade dos recursos.

Uma das quatro modalidades de convênios problemáticos analisadas diz respeito às entidades que já entregaram as prestações de contas, mas que ainda aguardam a análise do órgão que repassou o dinheiro. "Nessa modalidade, houve um aumento de R \$ 4,1 bilhões entre 2007 e 2008 dos recursos sem as análises determinadas pela IN 1/1997”. (LAMBRANHO E MILITÃO, 2008)

Cabe ressaltar os valores com prestações de contas recebidas, mas não analisadas de governos anteriores, que compõem o rol de convênios sem o devido cumprimento da lei.

No relatório de atividades de 2007, o Tribunal de Contas da União (TCU) "incluiu nessa categoria de repasses esquecidos (média de 5,4 anos de atraso) um total de $\mathrm{R} \$ 12,5$ bilhões, correspondente somente ao governo atual" (BRASIL, 2007c).

Isso permite, que convenentes ou beneficiados da transferência continuem a receber recursos públicos sem que tenham prestado contas ou que estas tenham sido aprovadas sem o lançamento da inadimplência.

O documento do TCU não poupa críticas à falta de controle sobre os repasses:

Nesse contexto, a ocorrência de desvios de recursos públicos é estimulada pela certeza da impunidade, em virtude da ausência de acompanhamento e da ineficiência dos órgãos transferidores de recursos para detectá-los. De modo geral, a permanecer o atual nível de descontrole dos recursos reservados às transferências voluntárias, torna-se impossível assegurar o alcance do interesse público. (BRASIL, 2007c).

Sobre esse aspecto, o Acórdão 788/2006 - Plenário (BRASIL, 2006b), destaca que "as falhas ocorrem devido à deficiências estruturais dos órgãos repassadores, controles inexistentes ou ineficientes e falta de servidores habilitados a analisar e fiscalizar a descentralização de recursos em número compatível com o volume de instrumentos celebrados.

Pela IN 1/97, "a partir da data do recebimento da prestação de contas, o órgão repassador tem 60 dias para se pronunciar sobre a aprovação ou não dos documentos apresentados por quem recebeu o dinheiro do governo". (BRASIL, 1997).

Para tentar se livrar desse passivo e acabar com a responsabilidade dos ministérios pelo descumprimento de uma determinação do próprio governo, o poder executivo publicou, uma portaria que arquiva os convênios mais antigos. A Portaria Interministerial 24 de 19 de 
fevereiro de 2008, "autoriza o arquivamento dos processos relativos aos convênios e contratos de repasse que tenham prazo de vigência encerrado até 25 de julho de 2002, valor registrado até R \$ 100 mil e cuja prestação de contas tenha sido apresentada até 31 de julho de 2007”. (BRASIL, 2008d).

Ainda segundo a portaria, "está vedado o arquivamento dos convênios quando esses estiverem submetidos a tomada de contas especial ou se forem objeto de denúncia". (BRASIL, 2008d).

Mas, nesse ponto, a norma do governo também se revelou inócua, pois existe um número grande de transferências que já deveriam estar sob a tomada de contas e não 'e o que os números demonstram.

Ainda segundo Lambranho e Militão (2008) “ao todo 9.291 convênios, que somam R\$ 1,1 bilhão de repasses, tiveram a prestação de contas rejeitada e constituem o grupo da chamada inadimplência efetiva".

Tabela 4: Convênios inadimplentes

\begin{tabular}{|c|c|}
\hline TOTAL R\$ & 1.115.086.423,71 (9.291 convênios) \\
\hline Com tomada de contas R\$ & $1777.654 .817,77$ (929 convênios ou $10 \%)$ \\
\hline Sem tomada de contas $\mathrm{R} \$$ & 937.431.605,94 (8362 comvênios) \\
\hline
\end{tabular}

Fonte: SIAFI

*Dados levantados de 1987 a 2008

Dados mostram que, apenas 929 convênios (representando 10\% do total de 9.291 convênios) têm tomadas de contas já instauradas. O restante ficou sem uma apuração mais cuidadosa. São 8.632 convênios cuja vigência terminou entre 1984 e 2008, com o prazo já vencido para a instauração do procedimento.

Pelo artigo 38 da IN 1/97, “o ministério ou órgão federal que repassou o dinheiro deveria tomar medidas para tentar reaver o dinheiro quando não for apresentada a prestação de contas no prazo de até 30 dias concedido em notificação pelo concedente". (BRASIL, 1997).

De acordo com a norma, o montante repassado deveria ser devolvido caso fosse confirmada a má aplicação dos recursos após a tomada de contas especial. A instituição que recebeu o convênio fica impedida de receber recursos federais até a regularização.

Portanto, mais uma vez a aplicação da norma não foi respeitada e evidencia-se claramente a falta de mecanismos eficazes de controle e fiscalização do montante cada vez maior de convênios realizados. 
Para completar o quadro de convênios sem a análise devida, o estudo em questão demonstra os convênios que estão com inadimplência suspensa.

Tabela 5: Convênios com inadimplência suspensa

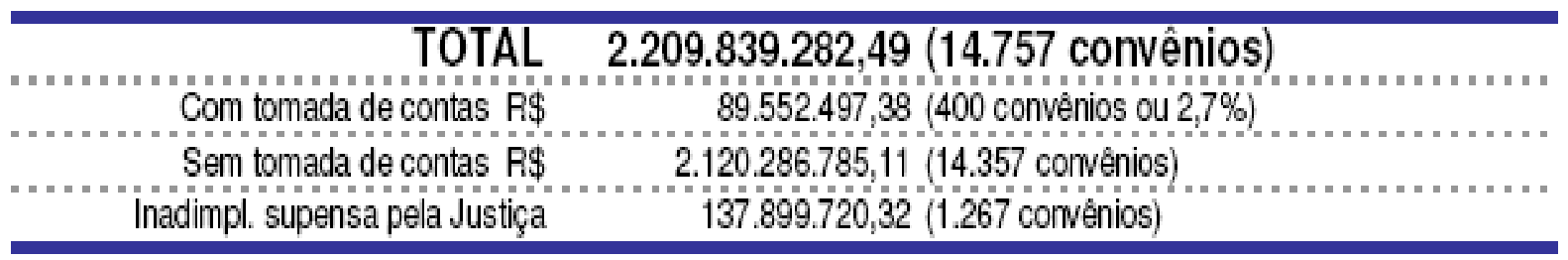

Fonte: SIAFI

*Dados coletados entre 1987 e 2008

São 14.757 transferências de dinheiro, representando $\mathrm{R} \$ 2,2$ bilhões de repasses cuja prestação de contas foi rejeitada.

Afirmam Lambranho e Militão (2008) que, "a inadimplência referente a R\$ 137 milhões foi suspensa por decisão judicial, na maioria dos casos, porque o gestor responsável pela irregularidade não é o atual dirigente da instituição. Caso, por exemplo, de ex-prefeitos”.

Nessa modalidade, todos os convênios, segundo instrução da STN, também deveriam ter tomada de contas especial instauradas, mas só 400 convênios com valor de R \$ 89 milhões, ou seja, apenas 2,7\% do total, já estão nessa fase de apuração.

Portanto, está clara a falta de agilidade e de ferramentas adequadas para auxiliar o processo de análise das contas, o que tem acarretado facilidades para recebimento de recursos, sem a comprovação da boa aplicabilidade do dinheiro público, caracterizando uma grave deficiência dos procedimentos de fiscalização e controle.

Partindo desses revezes, o Tribunal de Contas da União determinou ao Ministério do Planejamento, Orçamento e Gestão e aos demais órgãos e entidades da Administração Pública Federal que:

Apresente a este Tribunal estudo técnico para implementação de sistema de informática em plataforma web que permita o acompanhamento on-line de todos os convênios e outros instrumentos jurídicos utilizados para transferir recursos federais a outros órgãos/entidades, entes federados e entidades do setor privado, que possa ser acessado por qualquer cidadão via rede mundial de computadores, contendo informações relativas aos instrumentos celebrados, especialmente os dados da entidade convenente, o parlamentar e a emenda orçamentária que alocaram os recursos, se houver, o objeto pactuado, o plano de trabalho detalhado, inclusive custos previstos em nível de item/etapa/fase, as licitações realizadas com dados e lances de todos os licitantes, o status do cronograma de execução física com indicação dos bens adquiridos, serviços ou obras executados, o nome, CPF e dados de localização dos beneficiários diretos, quando houver, os recursos transferidos e a transferir, a execução financeira com as despesas executadas discriminadas analiticamente por fornecedor e formulário destinado à coleta de denúncias. (BRASIL, 2006c).

Dessa forma, o que o tribunal em questão propõe é um sistema informatizado que auxilie os órgãos repassadores de recursos a terem um maior controle sobre as transferências e 
que possibilite a transparência que deve ser dada às ações públicas e viabilize o controle social.

Assim, foi estabelecido o decreto 6.170 (BRASIL, 2007a) que "regulamenta os convênios, contratos de repasse e termos de cooperação celebrados pelos órgãos e entidades da administração pública federal com órgãos ou entidades públicas ou privadas sem fins lucrativos, para a execução de programas, projetos e atividades de interesse recíproco que envolva a transferência de recursos oriundos do Orçamento Fiscal e da Seguridade Social da União" e que institui o Sistema de Gestão de Convênios - SICONV.

Assim, está caracterizada uma nova era para a celebração, execução, fiscalização e controle dos convênios e outros instrumentos de repasse de recursos.

\title{
4.2. Principais mudanças ocorridas na legislação dos convênios
}

Desde 1997, quando foi implantada a IN/STN 01 (BRASIL, 1997), as transferências voluntárias da União mediante convênios, os contratos de repasse e termos de cooperação, eram balizados legalmente por esta norma. A partir de 2007, foi implantado o decreto 6.170 (BRASIL, 2007a), que passa a regulamentar a transferência desses recursos.

Sobre a criação do decreto, o manual da legislação Federal sobre convênios salienta:

\begin{abstract}
Buscando disciplinar os instrumentos de transferência voluntária entre a União e outra pessoa jurídica, o Decreto $n^{\circ}$ 6.170/2007 instituiu o Sistema de Gestão de Convênios e Contratos de Repasse (SICONV), cujas regras foram posteriormente detalhadas pela Portaria Interministerial $n^{\circ} 127$, de 29 de maio de 2008. Ambos os diplomas legais já foram aperfeiçoados pelos Decretos $n^{\circ} 6.329 / 2007, n^{\circ} 6.428 / 2008$,

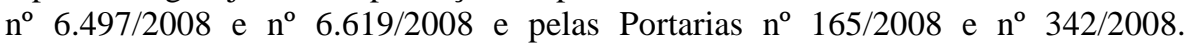
(BRASIL, 2008e).
\end{abstract}

Dentre as principais mudanças ocorridas na nova legislação, está a criação do Portal de Convênios, que contem o Sistema de Gestão de Convênios - SICONV, por onde toda a operacionalização dos convênios deverá ser tramitada, marcando assim uma nova era para a celebração, execução, fiscalização e controle das transferências voluntárias da União.

Segundo Santos (2008a), "haverá uma grande mudança em relação aos procedimentos atuais porque os atos de credenciamento, celebração, alteração, liberação de recursos, acompanhamento da execução do projeto e a prestação de contas serão viabilizados através da Internet".

Portanto, a criação do portal de convênios sinaliza a principal mudança implantada pelo decreto 6.170 (BRAISL, 2007a), onde o principal fator de inovação é a utilização intensa da rede mundial de computadores (internet), que permitirá o relacionamento mais dinâmico entre as 
instituições interessadas, bem como facilitará o conhecimento de toda a sociedade sobre como os recursos públicos federais estão sendo aplicados. Trata-se de uma mudança de paradigma, como se demonstrará mais à frente.

As diversas alterações, além da citada anteriormente, perpetuam por todas as fases do convênio.

$\mathrm{Na}$ primeira fase, para realizar a proposição de um convênio, apresentando sua proposta de trabalho, o interessado devera primeiramente se credenciar.

Sobre o credenciamento, a portaria $\mathrm{n}^{\circ} 127$ expõe que:

Art. 14. O credenciamento será realizado diretamente no SICONV e conterá, no mínimo, as seguintes informações:

I - nome, endereço da sede, endereço eletrônico e número de inscrição no Cadastro Nacional de Pessoas Jurídicas - CNPJ, bem como endereço residencial do responsável que assinará o instrumento, quando se tratar de instituições públicas; e II - razão social, endereço, endereço eletrônico, número de inscrição no Cadastro Nacional de Pessoas Jurídicas - CNPJ, transcrição do objeto social da entidade atualizado, relação nominal atualizada dos dirigentes da entidade, com endereço, número e órgão expedidor da carteira de identidade e CPF de cada um deles, quando se tratar das entidades privadas sem fins lucrativos. (BRASIL, 2008a).

Comparando a IN/STN/01/97 e o decreto 6.170 quanto ao credenciamento têm-se as seguintes diferenças:

\section{Credenciamento}

Ontem e hoje:

\begin{tabular}{|c|c|}
\hline IN STN N. ${ }^{\circ} 01 / 97$ & Art. $12^{\circ}$ a $14^{\circ}$ PORTARIA N. ${ }^{\circ} 127 / 08$ \\
\hline - Não previa & $\begin{array}{l}\text { - Credenciamento via Siconv } \\
\text { - Atualização: Convenente } \\
\text { - Pode ser condição para apresentação } \\
\text { de pleito }\end{array}$ \\
\hline
\end{tabular}

Instituições Públicas - nome, endereço da sede, endereço eletrônico e número $\mathrm{CNPJ}$ e endereço residencial do responsável que assinará o instrumento

ONGs - razão social, endereço, endereço eletrônico, número do CNPJ, transcrição do objeto social da entidade atualizado, relação nominal atualizada dos dirigentes da entidade, com endereço, número e órgão expedidor da carteira de identidade e CPF de cada um deles.

Quadro 2: Comparativo sobre credenciamento

Fonte: Bastos Neto. In: Semana Orçamentária. Brasília, DF, 2008.

Após o credenciamento devera ocorrer o cadastramento no SICONV. Sobre o cadastramento a portaria $\mathrm{n}^{\circ} 127$ define:

$\S 2^{\circ}$ No cadastramento serão exigidos, pelo menos:

I - cópia do estatuto social atualizado da entidade;

II - relação nominal atualizada dos dirigentes da entidade, com Cadastro de Pessoas Físicas - CPF;

III - declaração do dirigente da entidade: 
a) acerca da não existência de dívida com o Poder Público, bem como quanto à sua inscrição nos bancos de dados públicos e privados de proteção ao crédito; e

b) informando se os dirigentes relacionados no inciso II ocupam cargo ou emprego público na administração pública federal;

IV - prova de inscrição da entidade no Cadastro Nacional de Pessoas Jurídicas - CNPJ; e

$\mathrm{V}$ - prova de regularidade com as Fazendas Federal, Estadual e Municipal e com o Fundo de Garantia do Tempo de Serviço FGTS, na forma da lei.

$\S 3^{\circ}$ Verificada falsidade ou incorreção de informação em qualquer documento apresentado, deve o convênio ou contrato de repasse ser imediatamente denunciado pelo concedente ou contratado. (BRASIL, 2008a).

Evidenciando as mudanças ocorridas no cadastramento em relação à IN/STN/01/97 tem-se:

\section{Cadastramento}

Ontem e hoje:

\begin{tabular}{l|l}
\multicolumn{1}{c|}{ IN STN N. ${ }^{\circ} 01 / 97$} & Art. $17^{\circ}$ PORTARIA N. ${ }^{\circ} 127 / 08$ \\
\hline - Não previa & $\begin{array}{l}\text { - Via Unidade Cadastradora do SICAF } \\
\text { - Validade de } 1 \text { ano } \\
\text { - Representante vinculado à instituição }\end{array}$
\end{tabular}

- Cópia autenticada de documento de identidade e CPF.

- Cópia autenticada de documento que comprove competência para representar.

- Cópia de autenticada de procuração com firma reconhecida do dirigente máximo

Quadro 3: Comparativo sobre cadastramento

Fonte: Bastos Neto. In: Semana Orçamentária. Brasília, DF, 2008.

Dessa forma, toda a documentação referente aos proponentes do convênio ficara armazenada em um banco de dados, eliminando a documentação em papel, e quando da celebração de um outro convênio, por exemplo, com um Município, a entidade não mais necessitará dispor de outra documentação, pois esta já vai estar cadastrada no portal. Sendo apenas necessário a atualização das informações.

Outra novidade trazida pelo decreto 6.170 (BRASIL, 2007a) é quanto à padronização. A padronização é o estabelecimento de critérios a serem seguidos nos convênios com o mesmo objeto.

Sobre este aspecto, Santos (2008), argumenta:

O Governo Federal também poderá padronizar os projetos básicos dos empreendimentos mais freqüentes realizados por meio desses convênios, como escolas, postos de saúde e hospitais, dispensando a apresentação de 
projetos básicos por parte dos estados e municípios. Além de simplificar os procedimentos, também agilizará o repasse dos recursos, permitindo que os mesmos possam ser mais rapidamente aplicados em benefício dos cidadãos.

Realizando também um comparativo da fase de proposição do art. $2^{\circ}$ da IN/STN/01/97 com o Art. 15 da portaria 127/2008, tem-se:

\begin{tabular}{|c|c|}
\hline \multicolumn{2}{|c|}{ Proposição } \\
\hline Ontem e hoje: \\
Art. $2^{\circ}$ IN STN N. ${ }^{\circ} 01 / 97$ & Art. $15^{\circ}$ PORTARIAN. ${ }^{\circ} 127 / 08$ \\
\hline - Em papel: & - Via Siconv \\
I -Justificativa & I - descrição do objeto \\
II - descrição do objeto & II - justificativa \\
III - descrição das metas & III - estimativa dos recursos \\
IV - etapas ou fases & financeiros \\
V - plano de aplicação & IV - previsão de prazo para a \\
VI - desembolso; & execução \\
VII - declaração de mora; e & V- capacidade técnica e gerencial \\
VIII - comprovação do imóvel & \\
\end{tabular}

Quadro 4: Comparativo sobre proposição

Fonte: Bastos Neto. In: Semana Orçamentária. Brasília, DF, 2008.

Dessa forma, elimina-se toda a documentação em papel do objeto pactuado, que passa a fazer parte de um banco de dados único, onde as informações referentes a aquele convênio ficarão acessíveis.

$\mathrm{Na}$ fase de celebração do convênio, uma mudança importante que chama a atenção são algumas das hipóteses de vedação descritas na portaria da seguinte forma:

Art. 6 É vedada a celebração de convênios e contratos de repasse: I - com órgãos e entidades da administração pública direta e indireta dos Estados, Distrito Federal e Municípios cujo valor seja inferior a $\mathrm{R} \$ 100.000,00$ (cem mil reais);

II - com entidades privadas sem fins lucrativos que tenham como dirigentes, proprietários ou controladores:

a) membros dos Poderes Executivo, Legislativo, Judiciário, do Ministério Público e do Tribunal de Contas da União, bem como seus respectivos cônjuges, companheiros, e parentes em linha reta, colateral ou por afinidade até o $2^{\circ}$ grau; e b) servidor público vinculado ao órgão ou entidade concedente, bem como seus respectivos cônjuges, companheiros, e parentes em linha reta, colateral ou por afinidade até o $2^{\circ}$ grau; [...] (BRASIL, 2008a).

Assim, fica proibida a celebração de convênios e contratos de repasse com valores inferiores a $\mathrm{R} \$ 100.000,00$ para órgãos e entidades da Administração direta e indireta e com entidades privadas sem fins lucrativos que possuam como dirigentes, proprietários ou controladores membros do executivo, legislativo e judiciário e parentes até o segundo grau, 
como também com servidores públicos vinculados ao órgão repassador dos recursos e seus respectivos parentes até o segundo grau.

Uma outra grande inovação trazida pelo decreto 6.170 (BRASIL, 2007a), na fase de execução do convênio é com relação aos pagamentos. Realizando um comparativo entre as legislações demonstra-se que:

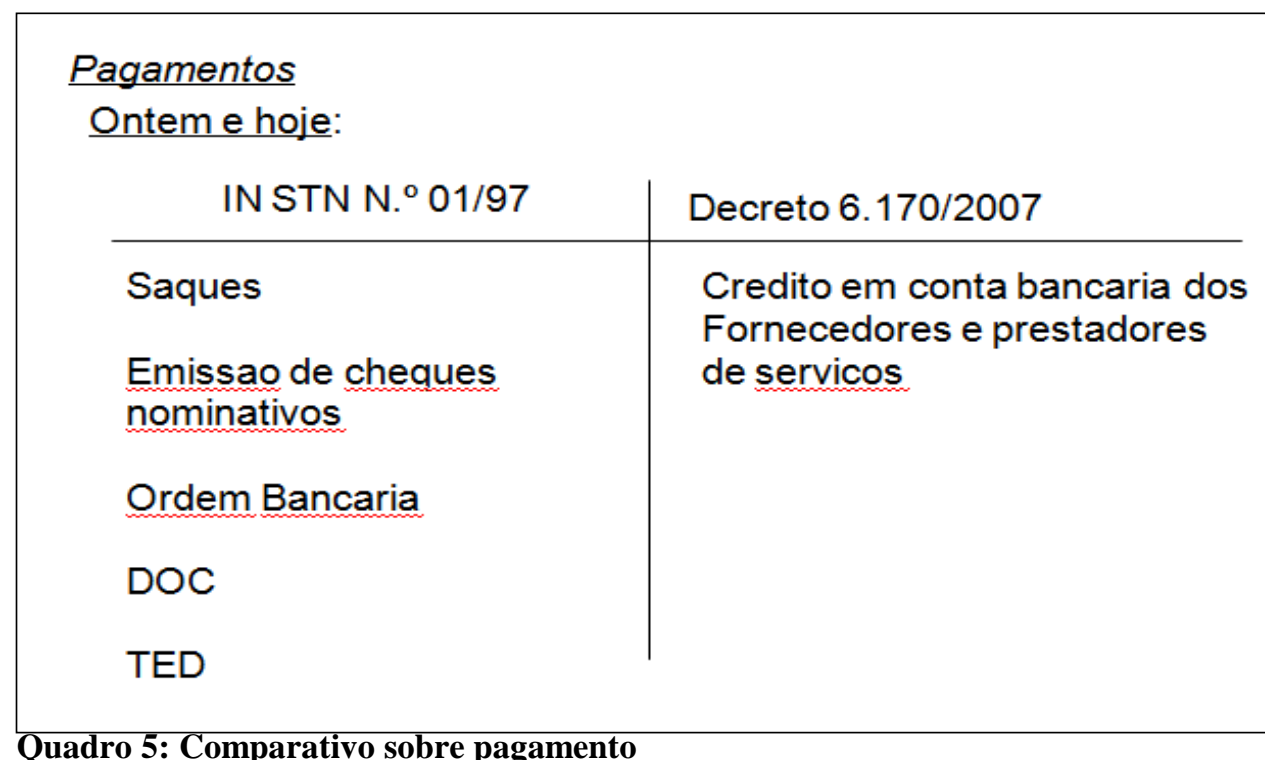

Quadro 5: Comparativo sobre pagamento

Fonte: Bastos Neto. In: Semana Orçamentária. Brasília, DF, 2008.

Enquanto na IN/STN 01 (BRASIL, 1997), os pagamentos realizados pelas entidades recebedoras dos recursos poderiam ser feitos por saque direto na conta do convênio, emissão de cheques e transferências eletrônicas, (o que muitas vezes dificultava e até impedia que se conhecesse o beneficiário final da movimentação financeira do convênio), com o decreto 6.170 (BRASIL, 2007a), toda a movimentação financeira do recurso deverá ser realizada por meio do SICONV, a partir de emissão de ordens bancarias. Os valores serão creditados em conta bancária especifica dos fornecedores e prestadores de serviços.

Dessa forma, toda a movimentação financeira do convênio ficará registrada e o beneficiário final será conhecido, o que vai facilitar os procedimentos de controle e fiscalização das transferências voluntárias.

Em função disso, analisa Santos (2008a), "foi suprimida a prestação de contas parcial e simplificado o rol de documentos necessários ao exame da prestação de contas. Essa modificação vai reduzir a burocracia e os custos de transação, além de ampliar a eficiência do processo de transferência de recursos ao evitar o acúmulo de processos com prestação de contas para serem analisados pelos ministérios".

Sobre a prestação de contas a portaria $\mathrm{n}^{\circ} 127$ determina: 
Art. 56. O órgão ou entidade que receber recursos na forma
estabelecida nesta Portaria estará sujeito a prestar contas da sua boa
e regular aplicação no prazo máximo de trinta dias contados do
término da vigência do convênio ou contrato ou do último
pagamento efetuado, quando este ocorrer em data anterior àquela do
encerramento da vigência.
$\S 1^{\circ}$ Quando a prestação de contas não for encaminhada no prazo
estabelecido no caput, o concedente ou contratante estabelecerá o
prazo máximo de trinta dias para sua apresentação, ou recolhimento
dos recursos, incluídos os rendimentos da aplicação no mercado
financeiro, atualizados monetariamente e acrescido de juros de
mora, na forma da lei.
$\S 2^{\circ}$ Se, ao término do prazo estabelecido, o convenente ou
contratado não apresentar a prestação de contas nem devolver os
recursos nos termos do $\S$ $1^{\circ}$, o concedente registrará a
inadimplência no SICONV por omissão do dever de prestar contas
e comunicará o fato ao órgão de contabilidade analítica a que
estiver vinculado, para fins de instauração de tomada de contas
especial sob aquele argumento e adoção de outras medidas para
reparação do dano ao erário, sob pena de responsabilização
solidária. (BRASIL, 2008 a).

De acordo com o texto da referida portaria, onde se determina que o dever de prestar contas do recurso recebido é de trinta dias, contados do termino da vigência do convênio ou contrato de repasse, apresenta uma inovação em relação à IN/STN/01 (BRASIL, 1997), que previa um prazo de 60 dias.

Com a inovação, diminui-se o tempo para prestação de contas, e não se prevê mais também a prestação de contas parcial, tendo somente a prestação de contas final, a ser realizada até trinta dias do término da vigência do instrumento firmado, ou do último pagamento efetuado, quando este incorrer em data anterior

àquela do encerramento da vigência, ou conforme estipulado no instrumento de celebração.

Santos (2008a) firma que "antes da implantação do SICONV, o acompanhamento da execução dos convênios e contratos de repasse era muito difícil de ser realizado, porque todos os processos estavam em papel e não havia ferramentas eletrônicas que permitissem à sociedade, à imprensa e aos órgãos de controle fiscalizar com eficiência o andamento dos convênios".

Portanto, a implantação do SICONV, significa a eliminação do papel na maioria dos processos, a desburocratização, a otimização dos processos de formalização dos acordos da União mediante convênios e outros instrumentos, como também facilita e agiliza a busca de informações pelos órgãos controladores e fiscalizadores dos recursos públicos, já que todos os dados estarão dispostos em um mesmo local. 
Dessa forma, a iniciativa também vai conferir mais transparência e ampliação ao controle social, pois será possível acompanhar a execução dos convênios e contratos de repasse pela Internet e verificar como esta sendo aplicado os recursos públicos transferidos.

\subsection{O Sistema de Gestão de Convênios - SICONV}

O Sistema de Gestão de Convênios e Contratos de Repasse - SICONV e o Portal de Convênios foram legalmente instituídos pelo Decreto $\mathrm{n}^{\circ} 6.170$, de 25 de julho de 2007, (BRASIL, 2007a).

O supracitado decreto determina que "a celebração, a liberação de recursos, o acompanhamento da execução e a prestação de contas dos convênios sejam registrados no SICONV, que será aberto ao público via rede mundial de computadores - internet, por meio de página específica denominada Portal dos Convênios, onde serão disponibilizados pelo Governo Federal todos os programas de transferências voluntárias”. (BRASIL, 2007a).

O SICONV foi desenvolvido pelo Ministério do Planejamento, Orçamento e Gestão MP - e esta disponível no endereço www.convenios.gov.br a partir de $1^{\circ}$ de julho de 2008 , data de início de vigência do Decreto $n^{\circ}$ 6.170/07.

Segundo Santos (2008b), o documento de visão do sistema - SICONV - tem como características e pressupostos básicos, "a ênfase na transparência à sociedade, redução do custo operacional, atendimento a todo o ciclo das transferências, facilidades para fiscalização e controle, simplificação/agilização de procedimentos, padronização, forte interatividade com demais sistemas estruturadores".

Dessa forma, o sistema deverá contemplar todo o ciclo da movimentação financeira do recurso possibilitando facilidades para o controle e fiscalização dos órgãos competentes.

Das características funcionais do sistema, as que merecem um maior destaque segundo Santos (2008b) são:

\footnotetext{
A criação de perfis de elegibilidade de convênio de acordo com as características do proponente, plano de trabalho detalhado, inclusive custos previstos, recursos transferidos e a transferir, status do cronograma de execução física, indicação dos bens adquiridos, serviços ou obras executados, licitações realizadas e ofertas de todos os licitantes, nome, CPF e localização dos beneficiários diretos, discriminação das despesas executadas por fornecedor, formulário destinado à coleta de denúncias e prestação de contas "pari-passo".
}

Assim, procurou-se prever todas as situações necessárias para ao acompanhamento das fases do convênio, focando principalmente na obtenção e cadastramento do maior número de informações. 
O sistema foi desenvolvido utilizando uma linguagem de programação em software livre, sob uma plataforma web, apresenta integração com outros sistemas oficiais do governo Federal, como receita federal, SIAFI (empenho; transferência; movimentação conta-corrente; GRU), Diário Oficial da União, CADIN e CAUC, Certidões Negativas Federais, integração com os bancos oficiais (abertura de conta), sistemas próprios de órgãos concedentes e convenentes. (SANTOS, 2008b).

Cabe ressaltar pela afirmação do autor a integração do SICONV com os sistemas estruturadores do Governo Federal, proporcionando assim uma maior agilidade na obtenção dos dados requeridos e também uma maior veracidade das informações obtidas, já que os sistemas integrados já possuem um nível de confiabilidade de grande excelência, como por exemplo, o SIAFI.

Para entender como o SICONV está estruturado, primeiramente será apresentado o seu fluxo operacional:

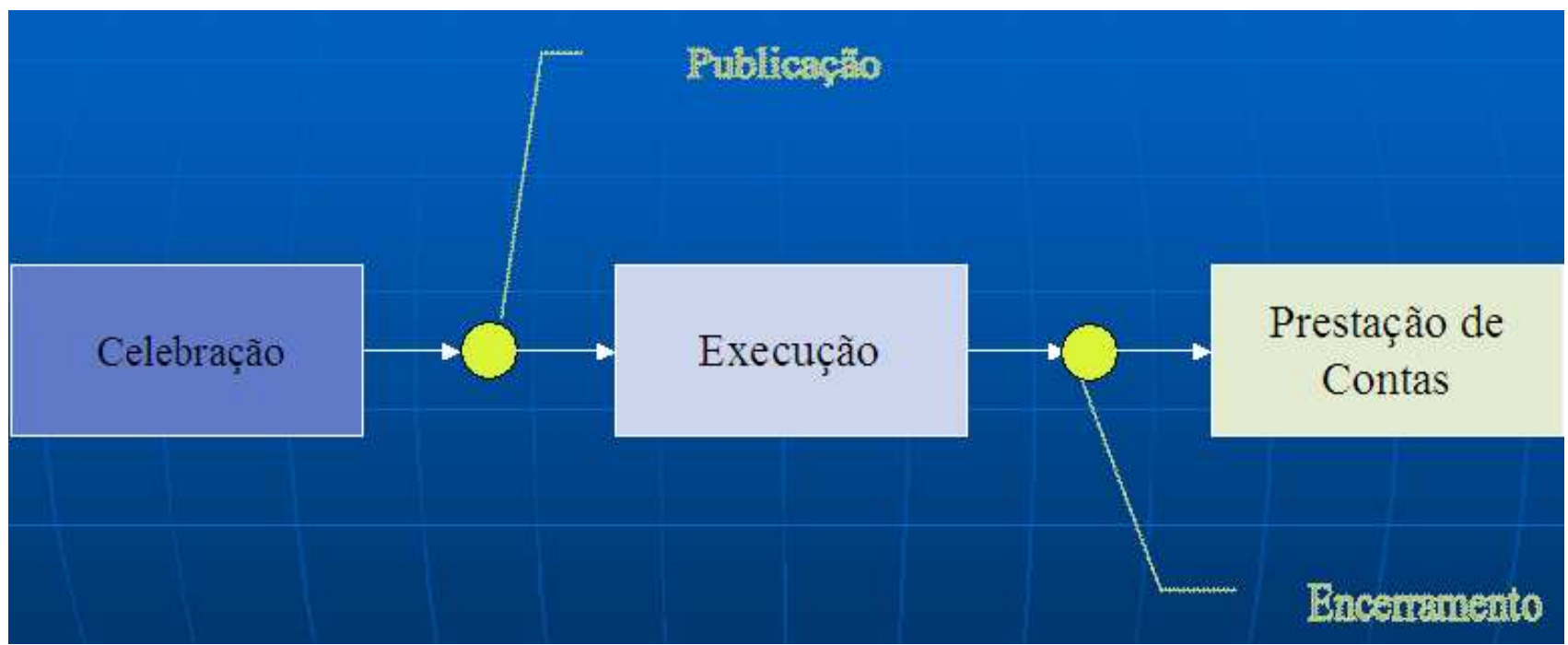

Figura 3: Fluxo operacional do SICONV

Fonte: Santos (2008b).

O fluxo operacional do sistema contempla todas as fases do convênio, desde a celebração do termo até o encerramento com a devida prestação de contas.

Dessa forma, três grandes módulos fazem parte do sistema, a celebração, a execução e prestação de contas, cada um deles abrangendo as diversas fases do convênio com características e atividades exclusivas de cada uma delas.

Segue o fluxo operacional de cada módulo: 


\section{Módulos da Celebracão}

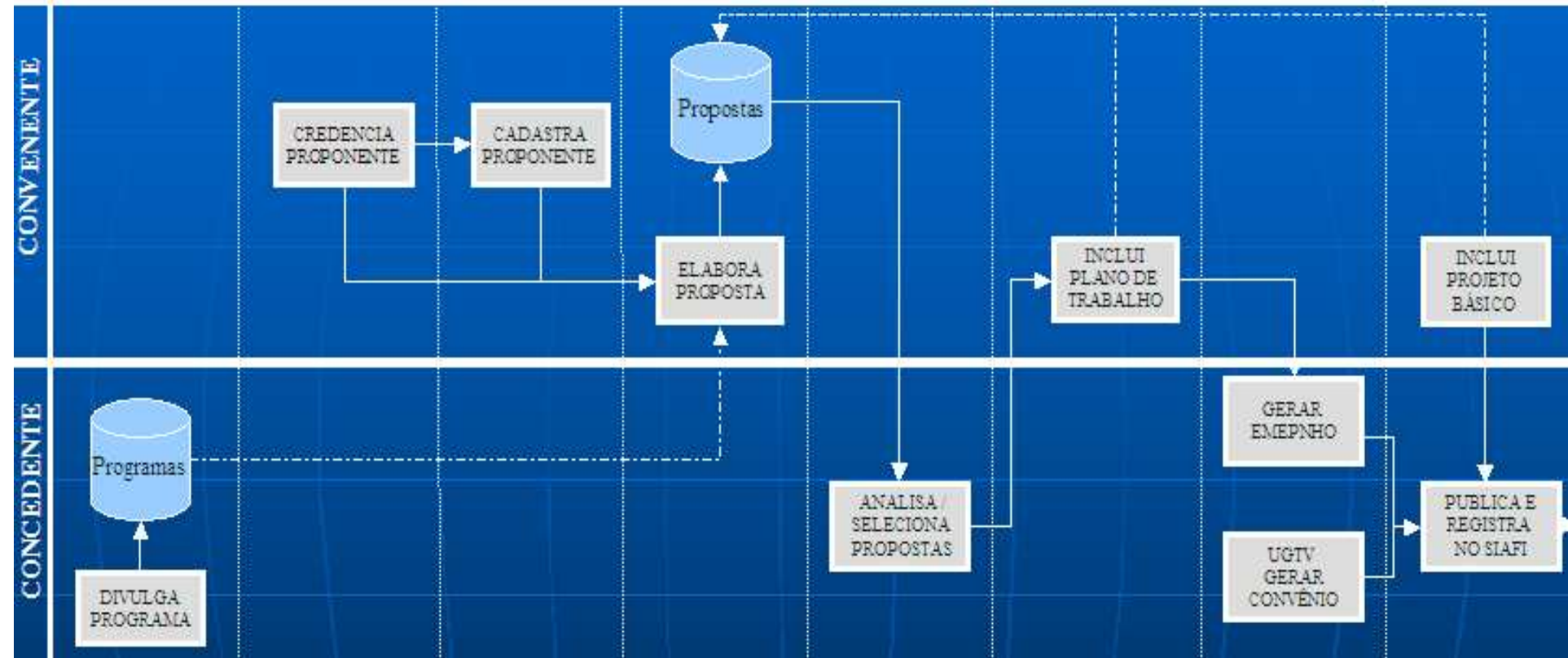

Figura 4: Módulo da celebração

Fonte: Santos (2008b).

De acordo com o fluxo de operacionalização do Sistema, temos de um lado o concedente, responsável primeiramente pela divulgação dos programas de transferências que estarão registrados no portal.

O convenente por outro lado, diante dos programas disponíveis, vai proceder com o seu credenciamento e cadastramento que, conforme já explicado neste estudo, é a disponibilização de todas as informações cadastrais do proponente.

"A responsabilidade pelos dados do cadastro do proponente é da unidade cadastradora, que aprova ou não o cadastramento". (BRASIL, 2008e).

Uma vez aprovado o cadastro, o proponente está apto a realizar convênios e os dados cadastrais, uma vez inseridos, podem ser aproveitados para a firmação de qualquer outro convênio.

O próximo passo é a elaboração e apresentação das propostas. "O proponente deve informar banco e agência, data da vigência e objeto do convênio, justificativa, e a contrapartida que deve ser depositada na conta do convênio pelo convenente". (BRASIL, 2008e).

O concedente analisa e seleciona as propostas que serão atendidas. A partir daí, o plano de trabalho é incluído de forma detalhada e registrado do SICONV.

Agora, o concedente pode gerar o número do convênio e a nota de empenho. "Neste momento, ele deve incluir o cronograma de empenho (data vencimento / recebimento e valor 
cronograma), enviar a minuta de empenho para o SIAFI, onde é gerado o número de empenho e número de lista de empenho. Pode-se também anular e reforçar o empenho". (BRASIL, 2008e).

O convenente, no momento do cadastramento já havia informado o banco e agência e no momento do empenho envia a conta bancária para o concedente realizar a abertura da conta corrente.

A seguir, "o concedente cadastra a UGTV, que será a Unidade Gestora da transferência voluntária". (BRASIL, 2008e).

Como todos os pagamentos deverão ser realizados por uma ordem bancária através da emissão de uma OBTV, para que o SIAFI contabilize a operação, sempre o beneficiário devera ser uma Unidade Gestora. Dessa forma, para cada CNPJ existe uma UGTV e para cada convênio existe um domicílio bancário.

"Quando aplicável, o convenente registra o projeto básico. É realizada a assinatura do convênio, então o concedente publica extrato no Diário Oficial da União e transfere dados do convênio ao SIAFI, gerando o cadastro reduzido da transferência voluntária". (BRASIL, 2008e).

É a formalização do convênio.

A partir desse ponto se inicia a execução do objeto do convênio apresentada a seguir:

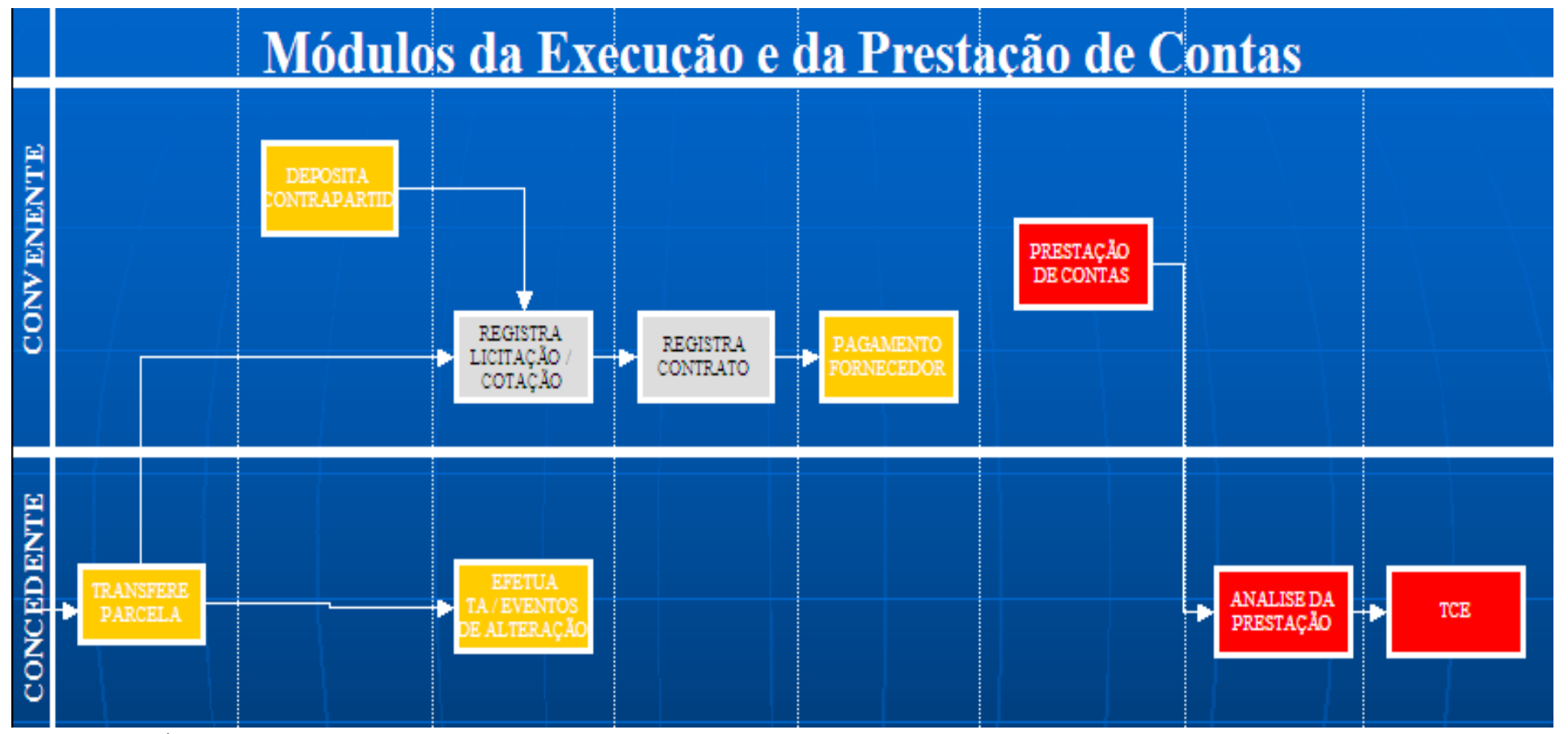

Figura 5: Módulos de execução e prestação de contas Fonte: Santos (2008b). 
No modulo de execução, conforme descrito no fluxo acima, primeiramente é depositada a contrapartida pelo convenente e parte ou todo o recurso é transferido para a conta do convênio pelo concedente. É o concedente liquidando a despesa do convênio. "Para a liquidação é gerada uma Nota de Sistema e o documento hábil”. (BRASIL, 2008e).

Realiza-se, o pagamento do convênio - transferência do dinheiro para a conta do convenente - é o desembolso do concedente.

De posse dos recursos, o convenente poderá dar inicio a execução do objeto e proceder com os tramites legais de contratação para a prestação do serviço.

Dessa forma, "o convenente deve registrar os licitantes e o resultado da licitação ou, no caso de ONG, a cotação prévia. Ele deve registrar também todos os contratos realizados”. (BRASIL, 2008e).

O convenente fiscaliza, registra os documentos e comanda o pagamento por meio de integração com os bancos oficiais, através da geração de uma ordem bancária de transferência.

Portanto, o beneficiário final do recurso somente poderá receber o pagamento, mediante a emissão de uma ordem bancaria de transferência, que devera ser registrada no SICONV.

"Na prestação de contas, o convenente complementa os registros do sistema com a relação de bens e serviços, a GRU do saldo, atestes, e demais documentos". (BRASIL, 2008e).

A seguir, o concedente analisa e aprova ou não a Prestação de Contas. No caso da não aprovação das contas, o concedente encaminha o processo para abertura de tomada de contas especial.

Portanto, de acordo com o fluxo apresentado, conclui-se que com o SICONV todas as fases do convênio estão sendo registradas, fazendo com que as informações necessárias estejam disponíveis ao acesso dos órgãos fiscalizadores, dos executores do convênio e também da sociedade em geral.

\subsection{A Tomada de Contas Especial e o SICONV}

Conforme descrito neste estudo, todo agente público tem o dever de provar a boa aplicação dos recursos públicos e são os órgãos de controle interno e externo que farão o acompanhamento simultâneo ou posterior da aplicação e gestão do dinheiro público. 
O controle interno é feito pela mesma unidade administrativa que praticou o ato ou por órgão específico instituído para fins de controle dentro do mesmo poder. (BRASIL, 2008e).

Tem-se aqui as figuras do controle administrativo e do denominado sistema de controle interno.

Na modalidade do controle administrativo, o próprio órgão ou autoridade responsável por conduzir determinada ação administrativa, pode e deve fiscalizar e corrigir, de ofício ou mediante provocação, o mérito e a legitimidade de todos os atos praticados no âmbito de sua competência, anulando os atos contrários à ordem jurídica e revogando os atos inconvenientes e inoportunos. (BRASIL, 2008e).

O sistema de controle interno é exercido pela Controladoria Geral da União, conforme já descrito neste estudo.

Com relação ao controle externo, existe o controle exercido pelo poder legislativo que desdobra-se em duas vertentes: o controle político realizado pelas casas legislativas e o controle técnico que abrange a fiscalização contábil, orçamentária e financeira, exercido pelo Tribunal de Contas da União. (BRASIL, 2008e).

A legislação aplicada aos convênios reconhece a importância desses mecanismos de controle da seguinte maneira:

\footnotetext{
Exige como cláusula obrigatória em convênios e contratos de repasse aquela que disponha sobre o livre acesso dos servidores dos órgãos ou entidades públicas concedentes ou contratantes e os do controle interno do poder executivo nacional, bem como o tribunal de contas da União aos processos.

Requer que a execução seja acompanhada e fiscalizada de forma a garantir a regularidade dos atos praticados e a plena execução do objeto. (BRASIL, 2008e).
}

O texto ressalta que toda documentação, processos e informações relativas aos convênios e contratos de repasse devem estar disponíveis para que o acompanhamento e controle da execução do objeto pactuado possa ser realizado pelos órgãos de controle interno e externo.

Partindo desse pressuposto, a portaria interministerial ressalta que todos os atos para o processo de fiscalização e acompanhamento deverão ser registrados no SICONV. (BRASIL, 2008a).

Dessa forma, todas as ocorrências relacionadas à consecução do objeto devem ser registradas no portal. Assim, o SICONV funcionará como um mecanismo de auxílio no acompanhamento e controle dos órgãos responsáveis, na medida em que conterá as principais informações sobre a execução do objeto, bem como da aplicação dos recursos públicos. 
Como todo gestor público é obrigado a prestar conta dos recursos utilizados, foi inserido no SICONV, o módulo de prestação de contas detalhado na figura a seguir:

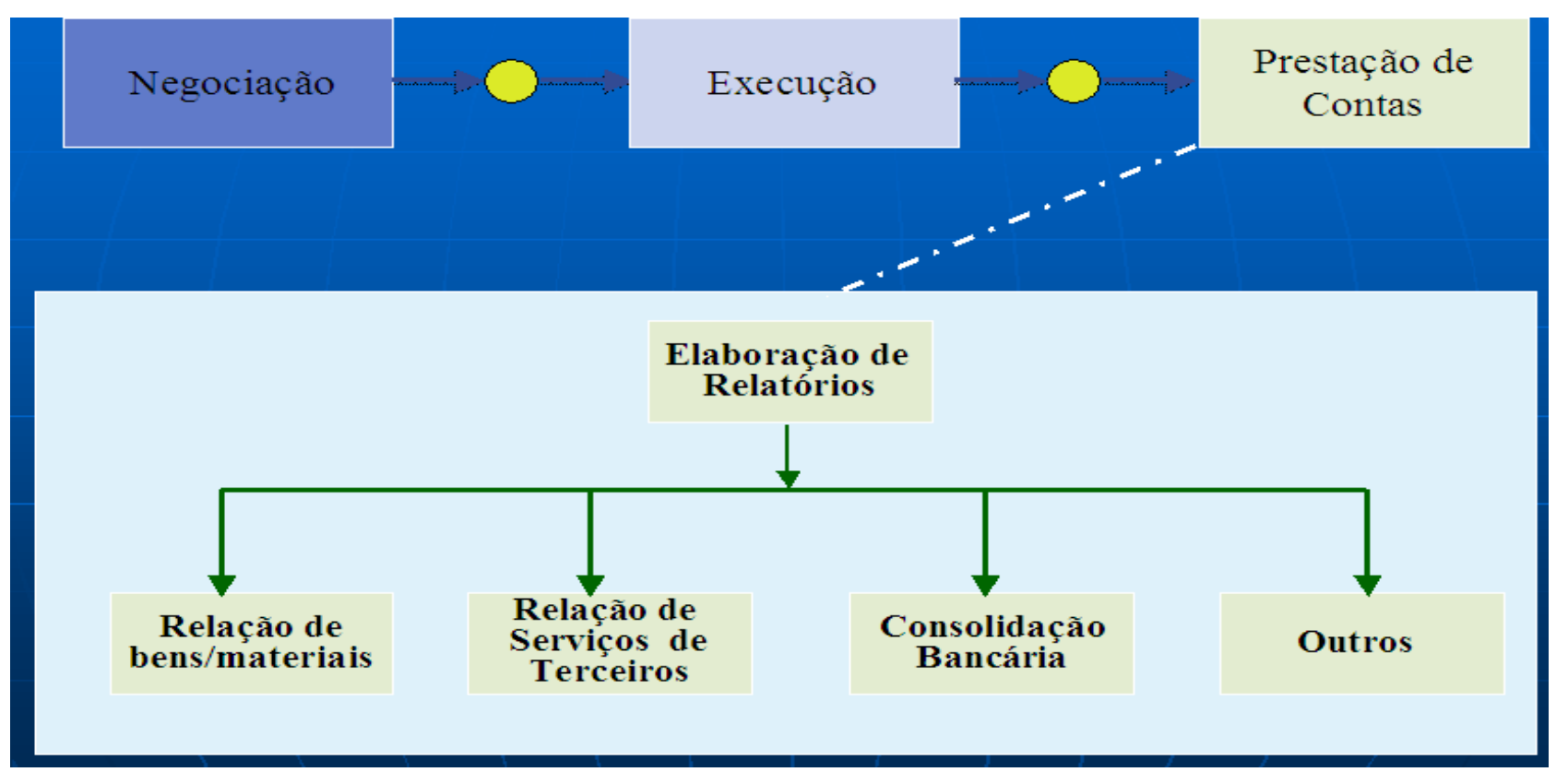

Figura 6: Fluxo da prestação de contas

Fonte: Santos (2008b).

A portaria interministerial suprimiu a prestação de contas parcial e simplificou o rol de documentos relacionados à conferência da prestação de contas, uma vez que os pagamentos e a conciliação bancária serão feitos on line. (BRASIL, 2008a).

O SICONV possibilitará o acompanhamento de todo o processo de prestação de contas, uma vez que as principais informações pertinentes à execução do objeto devem estar relacionadas contendo:

Relatório estabelecendo o cumprimento do objeto; declaração da realização dos objetivos propostos no instrumento; relação de bens adquiridos, produzidos ou construídos; relação de treinados ou capacitados, se houver; relação dos serviços prestados; comprovante de recolhimento do saldo de recursos, se houver; e o termo de compromisso por meio do qual o beneficiário será obrigado a manter os documentos relacionados ao convênio ou contrato de repasse por 10 (dez) anos contados da data em que foi aprovada a prestação de contas. (BRASIL, 2008 a).

Com isso, espera-se contribuir para a desburocratização, reduzir os custos da transação e aumentar a eficiência do processo de transferência de recursos e assim agilizar o processo de análise da prestação de contas, de forma a diminuir o acúmulo de processos com pendência de análise e comprovação.

Além disso, procura-se conferir maior transparência ao processo, uma vez que toda documentação sobre a execução do objeto estará disponível para o acompanhamento de toda a sociedade. 
A tomada de contas especial (TCE) é o procedimento administrativo que visa apurar responsabilidade daquele que der causa a perda, extravio ou outra irregularidade na qual resulte dano ao erário ou que não cumpra o dever de prestar contas. (BRASIL, 2008a).

Com base na definição, pode-se concluir que aquele que causar lesão aos cofres públicos ou não apresentar a prestação de contas, poderá ser responsabilizado, quando da apuração dos fatos, no procedimento de tomada de contas especial.

Em se tratando de convênios e contratos de repasse a tomada de contas especial poderá ser instaurada nos seguintes casos:

Omissão no dever de prestar contas; rejeição parcial, ou total das contas pelo órgão repassador dos recursos; irregularidades detectadas por ação dos órgãos fiscalizadores, procedidas de ofício ou a partir de denúncias e notícias divulgadas em veículos de comunicação indicando a prática de irregularidades em transferências voluntárias. (BRASIL, 2008e).

Portanto, em todos esses casos o procedimento de tomada de contas poderá ser instaurado, cabendo destacar as irregularidades detectadas pelos órgãos fiscalizadores, que poderão atuar em toda a execução do objeto pactuado, já que as principais informações estarão disponíveis para acompanhamento no SICONV, bem como as denúncias realizadas pela sociedade civil, que também poderão estar baseadas em irregularidades encontradas nas informações disponíveis no sistema.

A simples instauração da tomada de contas especial será suficiente para ensejar a inscrição da inadimplência no SICONV, o que será fator restritivo a novas transferências de recursos financeiros oriundos do orçamento da União para convênios e contratos de repasse. (BRASIL, 2008e).

Dessa forma o SICONV influencia no aumento da efetividade do processo de tomada de contas, haja vista que uma vez instaurado o procedimento, o convenente fica impossibilitado de receber recursos oriundos do orçamento.

Espera-se com isso aumentar a agilidade no processo de prestação de contas, uma vez que não é de interesse do convenente ficar impossibilitado de receber recursos e também no processo de apuração das irregularidades, uma vez que espera-se que se diminua o número de processos com instauração de tomada de contas especial. 


\section{Conclusão}

Constatou-se neste estudo que o processo de controle e fiscalização da aplicação dos recursos públicos transferidos voluntariamente pela União, mediante convênios, vem apresentando inúmeras fragilidades.

No período de 2002 a 2008, onde ficou evidenciado um aumento de mais de $80 \%$ nas transferências voluntárias da União, verificou-se que a atuação dos órgãos controladores não foi eficaz no sentido de desempenhar as ações de controle e fiscalização do gasto público no montante necessário para prevenir ou mesmo coibir fraudes na aplicação do recurso público.

Uma prova dessa falta de agilidade são os inúmeros convênios sem a devida prestação de contas, ou mesmo sem a análise da prestação de contas.

O conhecimento dessa fragilidade pelos maus gestores, vem proporcionando brechas para o aparecimento de fraudes e irregularidades na aplicação desses recursos, onde é cada vez mais difícil controlar e agir no sentido de bloquear e coibir essa má aplicação de dinheiro público.

Reconhecendo as ineficiências no processo de fiscalização e controle dos recursos, os órgãos controladores propuseram a implantação de um sistema de Gestão de Convênios, com a capacidade de armazenar e disponibilizar toda e qualquer informação necessária para a celebração, execução e prestação de contas das transferências voluntárias.

O sistema então, conforme descrito neste estudo, em um primeiro momento, tem a finalidade de credenciar os dados do proponente, cadastrar a proposta de trabalho, aprovar a proposta de trabalho e finalmente aprovar o plano de trabalho, contendo todos os objetivos e metas a serem cumpridos no convênio.

Isso proporciona um enorme ganho tanto para os convenentes, como para os concedentes, pois desburocratiza o processo, elimina a documentação em papel, como também elimina uma serie de rituais desnecessários que dificultam a vida dos estados, municípios, entidades sem fins lucrativos e ainda facilita o acompanhamento das metas descritas para o convênio e cronogramas de desembolso de recursos.

Em uma segunda fase, o sistema proporciona o acompanhamento da execução financeira do convênio, onde toda a movimentação do recurso ficara registrada no SICONV e a partir daí, todo o fluxo monetário estará delineado, facilitando a fiscalização da aplicação do dinheiro, pois estarão conhecidos todos os pagamentos e todos os beneficiários.

O Portal de Convênios fará o registro pormenorizado da movimentação financeira dos recursos repassados pela União, uma vez que o SICONV estará integrado aos bancos oficiais. 
Dessa maneira, as entidades e órgãos públicos que apresentarem irregularidades terão dificuldade em receber dinheiro público da União.

Estarão também descritos no SICONV todos os processos licitatórios e seus ganhadores.

Quanto à prestação de contas, como foi suprimida a prestação de contas parcial e simplificado o rol de documentos necessários ao exame da prestação de contas, será reduzida a burocracia e os custos de transação, além de ampliar a eficiência do processo de transferência de recursos ao evitar o acúmulo de processos com prestação de contas para serem analisados pelos órgãos concedentes.

E finalmente, quando da instauração da tomada de contas especial, o Tribunal de Contas da União, de posse de todas as informações sobre todas as fases do convênio disponíveis no SICONV, terá a possibilidade de auditar e promover as análises de uma forma mais rápida e eficiente, pois terá acesso a toda a documentação e toda movimentação financeira, que estarão armazenadas em um mesmo local, terá acesso aos responsáveis tanto no lado do convenente quanto do lado do concedente, como também a toda e qualquer informação sobre os processos licitatórios e seus beneficiários.

Com o SICONV, o processo de prestação de contas se torna mais ágil e o controle mais eficiente, pois as informações estarão disponíveis em tempo real e com muito mais transparência, porque o acompanhamento da execução dos convênios poderá ser realizado passo a passo pela Internet e a fiscalização da aplicação dos recursos pelos órgãos municipais, estaduais e ONG's ficará à disposição tanto dos órgãos controladores como de toda a sociedade. Até então, esse acompanhamento era muito difícil de ser realizado, porque todos os processos estavam em papel e não havia ferramentas eletrônicas que permitissem à sociedade, à imprensa e aos órgãos de controle fiscalizar com eficiência o andamento dos projetos.

Um outro ganho que essa ferramenta poderá trazer para o processo de tomada de contas de especial, e quanto à utilização de suas informações em ferramentas de Data Ware House ou de mineração de dados, possibilitando o cruzamento de diversas bases de dados e estabelecendo consultas gerenciais, de forma a agilizar o processo de fiscalização e obtenção de informações de forma mais objetiva e voltada para os aspectos de auditoria e controle.

Dessa forma, este estudo comprova que o Portal de Convênios é uma ferramenta viável que trará auxilio para o processo de análise da tomada de contas especial. Mas ainda não se tem como mensurar sua efetividade, pois como o SICONV foi implantado recentemente, não houve tempo hábil de se realizar uma medição de quanto de eficiência foi 
ganho no processo de prestação de contas e conseqüentemente da tomada de contas especial e de como o sistema esta contribuindo para a diminuição de fraudes na aplicação dos recursos públicos mediante convênios. Propoe-se esta análise para um próximo estudo, comprovando a eficácia ou não dessa poderosa ferramenta de gestão e controle da aplicação do dinheiro público. 


\section{REFERÊNCIAS}

ALMEIDA, Marcelo Cavalcanti. Auditoria: um curso moderno e completo. 5. ed. São Paulo: Atlas, 1996.

BASTOS NETO, Murillo M. Convênios, uma nova abordagem. In: Semana Orçamentária, 10, 2008, Brasília.

BASTOS NETO, Murillo M. Convênios e prestação de contas. Curitiba: Negócios Públicos, 2008.

BRASIL. Congresso Nacional. Relatório dos Trabalhos da CPMI "das Ambulâncias", criada por meio do requerimento $\mathrm{n}^{\circ}$ 77/2006-CN. Brasília, 2006a. Disponível em: <http://www.senado.gov.br/sf/atividade/Comissoes/comCPI.asp>. Acesso em: 3 nov. 2008.

Constituição da República Federativa do Brasil. Brasilia, 1988. Disponível em: <http://www.planalto.gov.br/ccivil_03/Constituicao/Constituiçao.htm>. Acesso em: 12 nov. 2008.

Decreto $\mathrm{n}^{\circ}$ 93.872, de 23 de dezembro de 1986. Dispõe sobre a unificação dos recursos de caixa do Tesouro Nacional, atualiza e consolida a legislação pertinente e dá outras providências. $\quad$ Brasilia, $1986 . \quad$ Disponível em: <http://www.planalto.gov.br/ccivil_03/decreto/D93872.htm>. Acesso em: 12 nov. 2008.

Decreto $\mathrm{n}^{\mathrm{o}} 3.591$, de 06 de setembro de 2000. Dispõe sobre o Sistema de Controle Interno do Poder Executivo Federal e dá outras providências. Brasília, 2000a. Disponível em: <http://www.planalto.gov.br/ccivil_03/decreto/D3591.htm>. Acesso em: 13 dez. 2008.

Decreto $\mathrm{n}^{\circ}$ 6.170, de 25 de julho de 2007. Dispõe sobre as normas relativas às transferências de recursos da União mediante convênios e contratos de repasse, e dá outras providências. Brasília, 2007a. Disponível em: <http://www.convenios.gov.br/legislacao.html>. Acesso em: 05 dez. 2008.

Decreto - Lei no 200, de 25 de fevereiro de 1967. Dispõe sobre a organização da Administração Federal, estabelece diretrizes para a Reforma Administrativa e dá outras providências. Brasilia, 1967. Disponível em: <http://www.planalto.gov.br/ccivil_03/DecretoLei/Del0200.htm>. Acesso em: 12 dez. 2008.

. Lei n ${ }^{\circ} 8.443$, de 16 de julho de 1992. Lei Orgânica do Tribunal de Contas da União. Brasilia, $1992 . \quad$ Disponível em: <http://www.tcu.gov.br/institucional/Legislacao/Organica/home.html>. Acesso em: 15 jan. 2009.

. Lei Complementar $n^{\circ} 101$, de 04 de maio de 2000. Estabelece normas de finanças públicas voltadas para a responsabilidade na gestão fiscal e da outras providencias. Brasília, 
2000b. Disponível em: <http://planalto.gov.br/ccivil_03/leis/lcplcp101.html>. Acesso em: 22 dez. 2008.

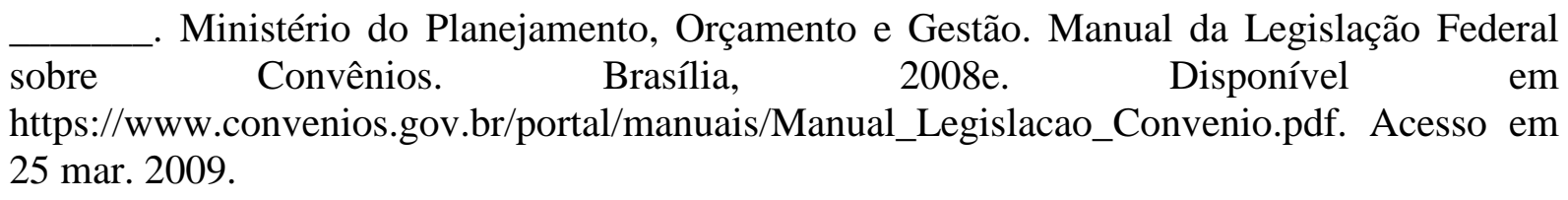

Portaria Interministerial $\mathrm{n}^{\mathrm{o}} 127$, de 29 de maio de 2008. Estabelece normas para execução do disposto no Decreto no 6.170, de 25 de julho de 2007, que dispõe sobre as normas relativas às transferências de recursos da União mediante convênios e contratos de repasse, e dá outras providências. Brasília, 2008a. Disponível em: <http://www.convenios.gov.br/legislacao.html>. Acesso em: 13 dez. 2008.

Portaria Interministerial $\mathrm{n}^{\mathrm{o}} 24$, de 19 de fevereiro de 2008. Disciplina os procedimentos operacionais para o atendimento ao disposto no art. 17 do Decreto no 6.170, de 25 de julho de 2007, e dá outras providências. Brasília, 2008d. Disponível em http://www.comprasnet.gov.br/legislacao/portarias/p24_08.htm. Acesso em 20 mar. 2009

Secretaria do Tesouro Nacional. Instrução normativa $n^{\circ}$ 1, de 15 de janeiro de 1997. Disciplina a celebração de convênios de natureza financeira que tenham por objeto a execução de projetos ou realização de eventos e dá outras providências. Brasilia, 1997. Disponível em: <http://www.stn.fazenda.gov.br/legislacao/download/contabilidade/IN1_97.pdf>. Acesso em: 19 dez. 2008.

Secretaria do Tesouro Nacional. Instrução normativa ${ }^{\circ}$ 4, de 17 de maio de 2007. Altera dispositivos, que especifica, da Instrução Normativa $n^{\circ}$ 1, de 15 de janeiro de 1997, disciplinadora da celebração de convênios de natureza financeira. Brasília, 2007b. Disponível em: <http://www.conveniosfederais.com.br/IN/in0407.htm>. Acesso em: 21 dez. 2008.

Tribunal de Contas da União. Acórdão N. ${ }^{\circ}$ 1.777/2005-TCU-Plenário. Ata 43/2005Plenário, Sessão 09/11/2005, Brasília, 2005. Disponível em: <https://contas.tcu.gov.br/portaltextual/PesquisaFormulario>. Acesso em: 03 jan. 2009.

. Tribunal de Contas da União. Acórdão N. ${ }^{\circ}$ 788/2006-TCU-Plenário. Ata 20/2006Plenário, Sessão de 24/5/2006, Brasília, 2006b. Disponível em: <https://contas.tcu.gov.br/portaltextual/PesquisaFormulario>. Acesso em: 05 jan. 2009.

Tribunal de Contas da União. Acórdão N. ${ }^{\circ}$ 2.066/2006-TCU-Plenário (Relatório e Voto). Ata 45/2006-Plenário, Sessão de 8/11/2006, Brasília, 2006c. Disponível em: <https://contas.tcu.gov.br/portaltextual/PesquisaFormulario>. Acesso em: 01 jan. 2009.

.Tribunal de Contas da União. Convênios e outros repasses. 2.ed. Brasília, 2008b.

.Tribunal de Contas da União. Regimento Interno. Aprovado pela resolução administrativa $\mathrm{n}^{\mathrm{o}} 15$, de 15 de junho de 1993. Brasilia, 1993. Disponível em: 
<http://www.tcu.gov.br/institucional/Legislacao/Regimento/home.html>. Acesso em: 05 jan. 2009.

Disponível

Tribunal de Contas da União. Relatório de atividades 2007. Brasília, 2007c.

http://portal2.tcu.gov.br/portal/page/portal/TCU/publicacoes institucionais/relatorios/relatorio s_atividades/Relatorio_Atividades_4-Tri-2007.pdf>. Acesso em 15 mar. 2009

BRITTO, Alzemeri Martins Ribeiro de; VALADÃO, Perpétua Leal Ivo. Convênios administrativos celebrados com entidades privadas: Necessidade de rediscussão do cabimento de seleção prévia e da possibilidade de aplicação de sanções administrativas. Salvador, 2007. Disponível em: <http://www.pge.ba.gov.br/Images/upload/File/talzemeri.pdf>. Acesso em: 13 Jan. 2009.

CARVALHO NETO, Antonio Alves de. Transferências de recursos do orçamento da União para Organizações Não-Governamentais: Análise dos procedimentos de concessão e controle. 2007. 146f. Monografia (pós-graduação em Orçamento Público) - Centro de Formação, Treinamento e Aperfeiçoamento da Câmara dos Deputados (Cefor); Instituto Serzedello Corrêa (ISC) do Tribunal de Contas da União, Brasília, 2007.

DI PIETRO, Maria Sylvia Zanella. Direito administrativo. 18.ed. São Paulo: Atlas, 2005.

FÊU, Carlos Henrique. Controle interno na Administração Pública: um eficaz instrumento de accountability. Teresina, ano 7, n. 119, 31 out. 2003. Disponível em: <http://jus2.uol.com.br/doutrina/texto.asp?id=4370>. Acesso em: 23 jan. 2009.

GARCIA, Ronaldo Coutinho. Descentralização: Um Processo a Ser Acompanhado e Avaliado (ou do finja que eu finjo ao faça que nós vemos). Ipea. Rio de Janeiro. Jan. 1995. Disponível em : < http://desafios2.ipea.gov.br/pub/td/1995/td_0364.pdf>. Acesso em 04 jan. 2009.

LAMBRANHO, Lúcio; MILITÃo Eduardo. Dinheiro Público a Deriva. Gazeta do povo, São Paulo, 08 dez. 2008. Brasília, 2008. Disponível em:

http://congressoemfoco.ig.com.br/DetEspeciais.aspx?id=25908. Acesso em: 20 dez. 2008.

MEIRELES, Hely Lopes. Direito Administrativo Brasileiro. 28.ed. São Paulo: Malheiros, 2003.

MIRAGEM, Bruno Nubens Barbosa. Convênios e consórcios administrativos: instrumentos jurídicos do federalismo brasileiro. Teresina, ano 4, n. 46, out. 2000. Disponível em: <http://jus2.uol.com.br/doutrina/texto.asp?id=457>. Acesso em: 13 nov. 2008.

MOREIRA, Márcia Maria. O controle interno como paradigma da administração pública gerencial. Teresina, ano 10, n. 890, 10 dez. 2005. Disponível em: <http://jus2.uol.com.br/doutrina/texto.asp?id=7569>. Acesso em: 29 dez. 2008. 
SA, Evelin Naked de Castro; RABELLO, Maria Celina Guimarães. Administração por convênios, um instrumento gerencial de políticas: uma análise dos convênios da Secretaria de Estado da Saúde de São Paulo - 1987. Rev. Saúde Pública, São Paulo, v. 22, n. 2, Apr. 1988. Disponível em: <http://www.scielosp.org/scielo.php?script=sci_arttext\&pid=S003489101988000200011\&lng=en\&nrm=iso>. Acesso em: 03 jan. 2009.

SANTOS, Ricardo Santanna. Portal de Convênios vai contribuir para desburocratizar o

Estado Brasileiro. Brasília, 01 set. 2008a. Disponível em $<$ http://www.governoeletronico.gov.br/noticias-e-eventos/noticias/portal-de-conveniosdesburocratiza-e-traz-maior-transparencia-aos-repasses-de-recursospublicos/?searchterm=portal\%20de\%20convenios>. Acesso em 18 mar. 2009.

SANTOS, Ricardo Santanna. Portal dos convênios: Um novo paradigma nas transferências voluntárias da União. Brasília, 2008b. Disponível em: <http://www.mp.gov.br/secretarias/upload/Arquivos/imprensa/pronunciamentos/apresentacoe s/081110_APRE_Convenios_sp_Rogerio_santanna.pdf>. Acesso em 20 mar. 2009.

SOUZA, Clayton Ribeiro de. Aplicabilidade do $§ 1^{\circ}$ do art. 65 da Lei $n^{0} 8.666 / 93$ aos convênios da administração pública. Teresina, ano 11, n. 1482, 23 jul. 2007. Disponível em: <http://jus2.uol.com.br/doutrina/texto.asp?id=10185>. Acesso em: 13 nov. 2008.

VIEIRA JUNIOR, Paulo Afonso. Controle da geração de despesa. XI Congreso Internacional del CLAD sobre la Reforma del Estado y de la Administración Pública, Ciudad de Guatemala, 7 - 10 Nov. 2006. Disponível em: <http://www.iij.derecho.ucr.ac.cr/archivos/documentacion/inv\%20otras\%20entidades/CLAD/ CLAD\%20XI/documentos/vieirajr.pdf >. Acesso em: 03 jan. 2009.

ZYMLER, Benjamin. O Controle Externo: O Tribunal de Contas da União. Brasília, 2001. Disponível em: <http://www.escola.agu.gov.br/revista/Ano_II_julho_2001/0507PalestraAGUBenjamin.pdf>. Acesso em: 15 jan. 2009. 